Öz

20. yüzyılın sonları ile birlikte etkisin güçlendiren neoliberal politikalar kentleri tüketilecek birer meta olarak pazara sunmus, kenti tüm özgünlüğünü kaybetme riski ile baş başa bırakmıștır. Hem yapısal hem de kültürel bir değișime uğrayan kentlerde; eşitsizlik, kutuplaşma gibi toplumsal ve mekansal ayrıșmalar gözlenmiştir. Bu süreç aynı zamanda kültürel ortamın dinamiklerini de yeniden belirlemiş; bienaller, müzeler, fuarlar ve festivaller ile kenti sekillendiren bir kültür endüstrisi yaratmıştır. Kapsamını İstanbul ile sinırlayan bu makalede, oluşan bu kültürel ortamda, neoliberalizm ile hız kazanan kentsel dönüşüm uygulamalarını sorunsallaștıran sanat eserleri ele alınmıștır. Böylelikle, sanatçıların pratikleri ile kent politikaları arasındaki ilişkilenmeyi anlamak; kentsel dönüșüm karșısında ne gibi üretimler gerçekleştirildiği, nasıl bir eğilim sergilendiği, kurulan ișbirlikleri, ortaya atılan çözümleri bir arada görmek

amaçlanmaktadır. Çalışmada, kent politikalarının tarihçesi ile güncel sanat ortamının yapısı ve kurumsallaşması üç dönemde incelenmiș, bu süreçte üretilen sanat eserleri araștırılmıștır. Bu eserlerin; periferiye odaklanan, farklı dilleri, melez kültürleri, azınlıkları görünür kılmaya çalıșan, yeni iş birlikleri icat ederek ekonomik ve hukuki süreçleri destekleyecek projeler üreten ve bir hafiza kaydı tutan, Rancière'den hareketle yeni olasılıklara ve yeni kurgulara zemin hazırlayan özellikler barındırdığı görülmektedir. Diğer yandan, özel şirketler aracılığıyla kurumsallaşan güncel sanatın bahsi geçen kentsel dönüșüm uygulamalarının tam da göbeğinde yer aldığ gözlemlenmiștir.

\section{Abstract}

Neoliberal policies, which strengthened their influence with the end of the 20th century, transformed cities into consumable commodities, and thus the cities faced the risk of entirely losing their unique nature. This rapid structural and cultural transformation led to a series of social and spatial divisions including inequality and polarization. At the same time, this process has assessed dynamics of the cultural environment and has created its own culture industry. Limiting its scope to Istanbul, this essay focuses on artworks that problematize urban transformation that accelerated as a result of neoliberalism. It is aimed to understand the relationship between the practices of artists and urban policies, to see what kind of productions are carried out in the face of urban transformation, what tendency is displayed, the collaborations and the solutions put forward. In this study, the historical process of urban policies and the structure and institutionalization of the contemporary art examined in three periods and the artworks produced in this process were investigated. These works have feature such as focusing on the periphery; making different languages, hybrid cultures, minorities visible; inventing new collaborations and projects to support economic and legal processes; keeping a memory record, setting the groundwork for

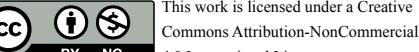
o sayı 32, Mart 2021

\title{
Kentsel Dönüşüm ve Güncel Sanat: Istanbul'da Yaşanan Kentsel Dönüşümü Sanat Eserleri Üzerinden Okumak
}

(iD) Eda Gecikmez Hacettepe Üniversitesi Güzel Sanatlar Enstitüsü, Resim, Sanatta Yeterlik

Başvuru tarihi/Received: 07.08.2020, Kabul tarihi/Final Acceptance: 21.01.2021

Giriş

Sitüasyonistler 1960'da yayınladıklar1 Enternasyonal Manifesto'da, hayatı örgütleyerek eyleme geçirdikleri bütünsel bir pratik olarak kültürün, tüm gezegeni kapsayabilecek ve yaşanabilir tüm gezegenlere uzanabilecek dinamik bir birleștirici kent planlaması olarak görür (Debord 2011). Geç kapitalist sömürücülüğün merkezi olan kentin haritası saptırılıp, bölünüp ve eleștirive maruz bırakıldığında, devrimci enerjiler ve dönüştürücü potansiyel açığa çıkabilecektir (Mc Donough 2004). $\mathrm{Bu}$ "durum"un yaslandığ hayatı ele geçirmeye yöneldiği bir mücadele tarihine dayanır: Modernliğin rasyonel despotizminden, postmodernizmin gösteri kültürüne uzanan, toplum ve kent üzerinde baskı kuran iktidarın sorgulanmasına dayanan bir direniş geleneği. Sanatın bu devrimci, dönüştürücü ve direngen gücü verili olana, baskı kurana karşı gelmesinden ve somut olasılıkların olduğu başka bir gerçekliğe yeni bir boyut açmasından gelir: özgürleşmenin boyutu (Marcuse 1991). Bu yönüyle sanat toplumsal mücadelelere iç içe geçer; tıpkı Sitüasyonistleri 60'ların toplumsal hareketlerinden ayrı ele alamayacağımız gibi, neoliberal küreselleşme karșıtı hareketlerle güncel sanatın politik tavrının karşılıklı şekillendiğini söyleyebiliriz (Kuryel ve Firat 2015).
Soğuk Savaş sonrası kurulan yeni dünya düzeninde sanat hızla kurumsallaşarak kendi endüstrisini yaratır. Kültür endüstrisi artık yönetilen, kitlelerin bilincinde spekülasyon yapan, kâr odaklı, iktidar, statü ve gösteriş ifadesine dönüşür (Adorno 2008). Bu endüstri özellikle 1980'lerden sonra tüm dünyada etkisini göstermeye başlayan neoliberal politikalar ile serbest piyasa adı altında ekonomik gücün ulus-devletlerden kentlerde merkezileșen sermaye gruplarına yani özel şirketlere geçmesiyle giderek büyür. Bu şirketler daha önce kamusal olarak görülen kültür ve sanat alanına sponsorluklar, mali yatırımlar şeklinde müdahale etmeye başlar, böylece yarattıkları kültürel sermayeyi siyasi bir güce dönüştürür ya da kendi çıkarları için kullanırlar (Wu 2005). Siyaset de kamuoyu yoklamalarının ve devasa siyasi eğlence sektörünün elbirliğiyle işleyen bir gösteri olarak estetikleşir (Kreft 2014). Yani denilebilir ki, sanat bu neoliberal dünyanın tam da göbeğinde yer alır (Steyerl 2013).

Tipk1 sanat gibi, kentler de neoliberal politikalar ile hem bir yerleşke hem de bir tür yatırım ve rant aracı olarak dönüşür. "Küresel Kent, Dünya Kenti” şeklinde tanımlanan bu kentler, dünya ekonomisinde bir yer edinmek isteyen, birbiriyle büyük rekabet içinde olan, uluslararası sermayeyi kendine çekmek ve yatırımları kazanmak için her 
new possibilities and fictions based on Rancière. On the other hand, it has been observed that contemporary art, which has been institutionalized through private companies, is at the heart of the urban transformation.

Anahtar Kelimeler: Kentsel dönüşüm, neoliberalizm, İstanbul, güncel sanat, kültür endüstrisi.

Keywords: Urban transformation, neoliberalism, Istanbul, contemporary art. culture industry. türlü ekonomik ve politik işleyişte değişiklere gidilen, yani küresel sermayeye göre yönetilip biçimlendirilen kentlerdir (Sassen 1991; Friedmann ve Wolff 1982). Merkezi ve yerel hükümetler, küresel kent uygulamalarını meşrulaştırmak için birbirine benzeyen politikalar üretmiş; planlama sisteminin esnekleştirildiği, özel sektöre ağırlık veren, ekonomik yenilenme, canlanma ve gelişme amacıyla kentsel dönüşüm projeleri gerçekleştirmiştir (Öktem 2006).

Kentsel dönüşüm projeleri, ilk olarak İkinci Dünya Savaşı sonrası yıkılan kent merkezlerinin yenilenmesi olarak uygulanırken, 1960'lara gelindiğinde yeniden yatırım için cazip hale gelen alanların soylulaştırma adı altında kentsel yap1lanması olarak karşımıza çıkar (Şen 2005). 1980'lerden itibaren ise neoliberal politikalar ile birlikte daha çok ekonomik hedefler doğrultusunda uygulanır (Balaban 2013). Bu müdahaleler neoliberal kentleşme adı altında küresel kentsel stratejiler olarak sunulur, yerel yönetimler ve özel sermaye gruplarının ortak çalışmasıyla yeni bir kent politikası geliştirilir (Smith 2002). Sanayisizleşme ile birlikte kent içinde kalan kapanmış sanayi yapıları ve etrafinda yer alan görece alt gelir gruplarının yerleştiği alanlar, global pazar için önemli yatırım mekanlarını oluşturur. Aynı şekilde kenti dünyaya tanıtma, pazarlama, imaj ve markalaşma amaciyla kentin tarihi dokusu temizleme ve yenilemeye açılır. Benzer sürecin yaşandığı Türkiye'de de kentsel dönüşüm projeleri özellikle konut sıkıntısı ve ekonomik kalkınma öne sürülerek uygulanmaya başlanmış fakat son yıllarda görüldüğü üzere kâr ve rant amaçlı bir güç mücadelesine dönüşmüş; toplumda yoksulluk ve dişlanma, ekonomik ve sosyal ağların kaybedilmesi, güvencesiz yaşam pratikleri ve mülksüzleşme ortaya çıkmıştır (Türkün 2014).

Kurumsallaşan sanat, yoksul semtlerdeki halkın yerinden edilme sürecinin tam ortasında yer alarak; spekülasyon, kentlerin pazarlanması, markalaştırma ve kültürel mühendislik gibi girişimlere dahil olur (Emmelhainz 2013). Kültür kurumlarının başını çeken müzeler bulunduğu kentte ya da bölgede hayat kalitesini yükseltmek ve ekonomik büyümeyi hızlandırmak gibi yeni anlamlar edinmiştir (Barker 2006). Kentin imgesini güçlendiren, merkezleri canlandıran, marka yaratarak prestij sağlayan, rekabette büyük rol oynayan müzeler özellikle star mimarların gösterişli yapılarıyla yaygınlık kazanmıştır. Bu anlamda müzeler zenginliğin getirdiği prestiji sergilemesi; rekabette büyük rol oynaması ve marka yaratması; geniş mekanlar gerektirmesi; boş zamanları geçirme tarzını şekillendirmesi; büyümesi ve yayılması ile sanat üretimini arttırması gibi etkilerde bulunur (Stallabrass 2009). İstanbul'da bunun en son örneği olarak 2019 yılında Dolapdere'de Grimshaw Architect tarafindan tasarlanan binasıyla Koç Holding'e ait Arter'den bahsedebiliriz. Aynı mimarlık ofisinin İstanbul Havalimanı inşa ekibinin içinde de yer aldığını görüyoruz.

Ne var ki, neoliberal politikaların kent ve sanat üzerindeki bu karmaşık ilişkisine / tahakkümüne karşın, en başta bahsedilen direniş geleneğini çeşitli yöntem ve yaratıcılıkla sürdüren sanatçıların olduğunu; özellikle kentsel dönüşümün kendisi ve etkilerinin birçok sanatsal çalışmanın konusu haline geldiğini görmekteyiz. Jacques Rancière, siyasi özne olarak sanatçılar ve kültür üreticilerinden bahsettiği makalesinde, sanatı sadece siyasi meselelerle uğraştığı ya da sosyal ve siyasal çatışmaları temsil ettiği için siyasal olmadığını; mekanın, görünürlüğün ve yaşanırlığın dağılımını yeniden biçimlendirdiği için siyasi olduğunu söyler. Sanat, tahakküm altına alınmış zaman ve mekanı yeni bir algı modeli yaratarak tekrar biçimlendirir; var olan kurguları değiştirerek yeni kurgular üretir. Kurgular üretmek gerçeğin var olan manasını kuran bağlantıları çözüp yeniden ifadelendirmek, söylenebilir ve yapılabilir arasında yeni yörüngeler icat etmek, tanımlamaların sınırlarını belirsizleştirmek ve yerinden etmek anlamına gelmektedir (Rancière 2007). Böylece yıkıcılaşan sanat kendine özgü estetik dili kullanarak yerleşik gerçekliği gelmesi hala beklenen uzlaşma uğruna 'paranteze alır' ve hükümsüz k1lar (Marcuse 1991). 
Bu araştırma, 1980'li yıllardan günümüze İstanbul özelinde kentsel dönüşümü konu edinmiş bu sanat eserlerinin izini sürmektedir. Sanatçıların pratikleri ile kent politikaları arasındaki ilişkilenmeyi anlamak, kentsel dönüşüm karşısında ne gibi üretimler gerçekleştirildiği, nasıl bir eğilim sergilendiği, kurulan işbirlikleri, ortaya atılan çözümleri bir arada görmek amaçlanmaktadır. Aynı zamanda neoliberal politikaların tüm dünyayı homojenleştiren müdahalelerine karşı sanatın ürettiği bilgi yereldeki yansımalarını görünür kılabiliyor mu sorusunun da yanıtı aranmaktadır. Oldukça geniş ve de dağınık olan bu üretimler, son 40 yıl içerisinde yer alan birçok öncü sergilerin ve etkinliklerin arşivleri; basılı ve dijital yayında çıkan haberler, söyleşiler ve eleştiri yazıları taranarak araştırılmıştır fakat makalenin sınırları gereği bu çalışmaların hepsine yer vermenin mümkün olmadığı akılda tutulmalıdır. Bu bakımdan ele alınan sanat eserleri İstanbul'da uygulanan kent politikalarının bir haritasını ortaya çıkaracak şekilde, mümkün olabildiğince farklı durum ve mekanlara işaret etmeleri üzerine tercih edilmiştir.

\section{İstanbul'da Uygulanan Kent Politikalart ve Güncel Sanat Ortamı}

İstanbul'da uygulanan kentsel politikaların tarihçesine ve aynı süreçte gelişen güncel sanat ortamının dinamiklerine bakıldığında 1980 tarihi öne çıkar. Bu tarihten günümüze kadar yaşanan gelişmeler değerlendirildiğinde kabaca 3 dönemden bahsetmek mümkündür: Askeri darbe ve sonrasında tamamen değișen siyasal paradigma, AKP iktidarı ve Gezi Parkı direnişi sonrası. Bu dönemlerde öne çıkan gelişmeleri özellikle kentsel dönüşüm bağlamında konu edinmiş ve eser üretmiş sanatçılara yer verilmiştir.

\section{0 - 2000 Yillart}

Küresel neoliberal politikalar, Türkiye'de 24 Ocak 1980 Kararları adı altında yürürlüğe girmiş ve askeri darbenin hüküm sürdüğü bir ortamda hızla çıkarılan kanunlar eşliğinde hayata geçirilmiştir. Alınan bu kararlar ile hızlı bir sanayisizleşme sürecine gidilmiş, daha çok tüketim ve kültür endüstrisine yönelik yatırımlar yapılmıştır.
Bankacılık, sigorta, medya şirketleri gibi hizmet sektörü için yapılaşma; turizm sektörü için tarihi alanlarda canlandırma projeleri devreye girmiştir. İstanbul'un tarihi ve kültürel sermayesini pazara sunan bu politikalar, kenti bir reklam malzemesine dönüştürmüştür. Başta emlak piyasası ve turizmi kapsayan projelere daha sonra kültürel alanlar da eklenmiş, kentsel mekanlar çok uluslu ve yabancı firmaların tüketimine açılmıştır.

1937'de kamusal alanlar yaratılması hedeflenen ilk kapsamlı plan olan İstanbul Nâzım Planı, 1950'lerden itibaren zaafa uğratılmaya başlamış, dış yardımlarla kurulan montaj sanayi ve otomobil sektörü için uygulanan karayolu projeleri kentin ilk y1kım sürecine yol açmıştır (Yllmaztürk 2018). 1942'de Varlık Vergisi, 1955'te 6-7 Eylül Olayları kent merkezinde yaşayan gayrimüslim nüfusun iş yerleri ve konutlarını terk etmesine sebep olmuştur.

1980'lerden itibaren sanatçıların ilgisinin kente kaydığını, şehri sosyolojik bir olgu olarak çalışmalarına konu ettiğini görüyoruz. Bunun öncü bir örneği olarak Sarkis'in, gayrimüslim nüfusun yerinden edilmesini kendi kişisel tarihinden yola çıkarak gerçekleştirdiği Çaylak Sokak adlı yerleştirmesinden bahsedebiliriz. Sarkis, 1986 yılında Maçka Sanat Galerisi'nde, doğduğu ve büyüdüğü sokak olan Çaylak Sokak'a ait nesneleri galeri mekanında yeniden kurgulamıştır. Kunduracının tezgâhı, radyo, banyo, tablo, akbaba heykeli, ses kayıt bantları, babasına ait ayakkabılar, metal konstrüksiyon, Çaylak Sokak levhas1... gibi eşyalarla kişisel yaşam öyküsüne ve kolektif geçmişe dayanan bir mekan deneyimi sunar (Sekil 1).

1984 yerel seçimlerinde İstanbul Büyükşehir Belediye Başkanı seçilen Bedrettin Dalan dönemi ile kentte ikinci büyük yıkım süreci yaşanmıştır. Bu dönemde Tarlabaşı Bulvarı açılmış, Boğaz, Marmara ve Haliç sahil yolları yapılmış; Karaköy, Eminönü, Üsküdar gibi meydanlar inşa edilmiştir. Tarihi yarımadada 19.yy'dan kalma mahalleler yol açmak ya da güzelleştirme için yıkılmıştır. 1990'lı yıllara gelene kadar, çevre yolları ve iki Boğaz köprüsü 


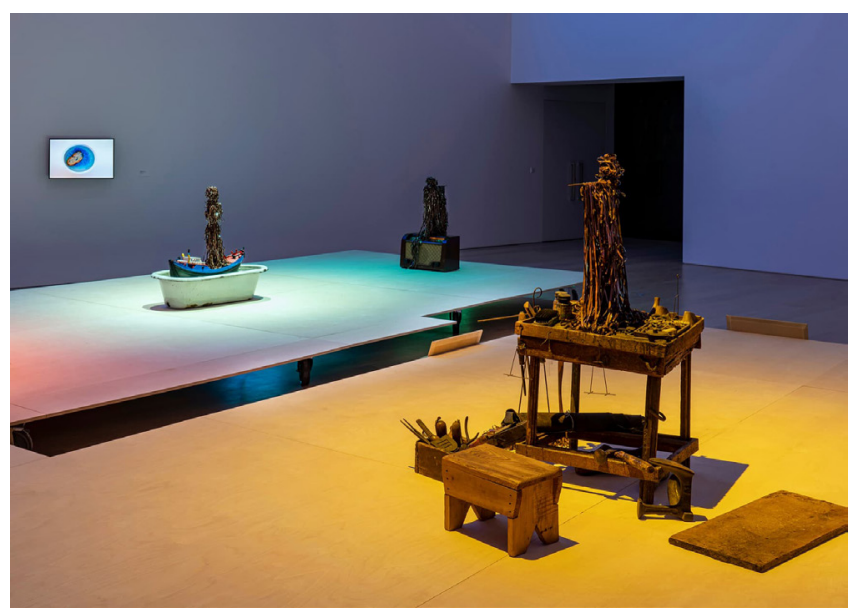

şekil: I

sarkis, f̧aylak Sokak,1986, saat Kaç? sergisinden görünüm, 2019, Arter Koleksiyonu, fotoğraf: flufoto (Arter'in izniyle).

şekil: 2

Ayse Erkmen, Taklit, yerlestirme, 1987 (sanatçının izniyle). giderek artmıştır.

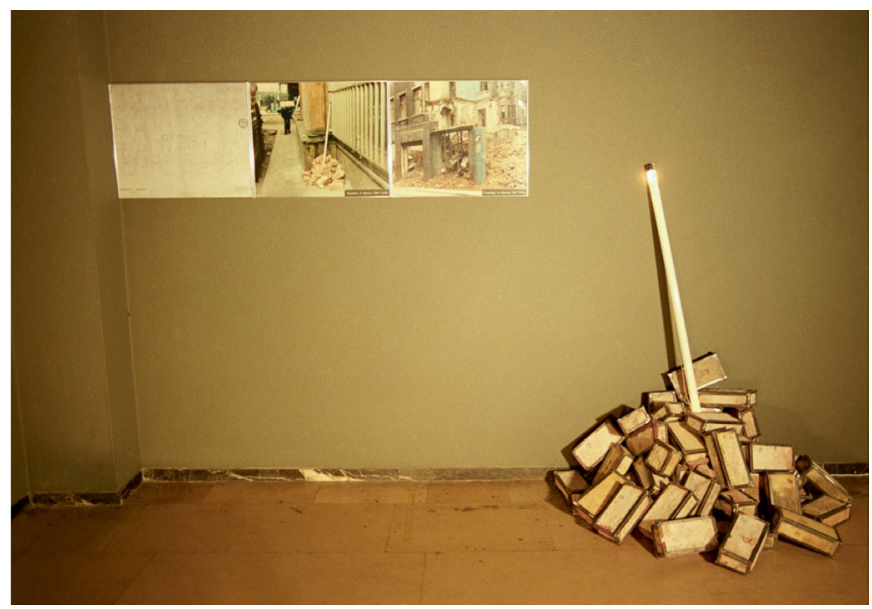

ile İstanbul sanayi ve endüstri merkezine dönüşmüş, kentin nüfusu göç dalgaları ile

Sanatçı Ayşe Erkmen, 1987'de, muhtemelen bu yıkımlardan toplanılan tuğlalarla gerçekleştirdiği Taklit isimli yerleştirmesinde izleyiciyi kamusal alandaki gündelik bir an ile ilişkilendirme niyetindedir. Duvarda asılı olan Tarlabaşı ve Karaköy yıkımlarından çekilen fotoğraflardaki tuğla yığınlarını galeri mekanında yeniden gerçekleştirerek her gün karşılaşılan bir olgunun estetik durumunu sorgular (Şekil 2).

Sanayileşme sonrası kırsal kesimden kente göç edenler yeterli konut sağlanamadığ 1 için ya 50'lerde terkedilmiş kent merkezine ya da çeperdeki hazine arazilerine gecekondular halinde yerleşmiş, böylece kentin toplumsal yapısı oldukça değişmiştir. Bu yoksul kesimler arabesk olarak adland1rılan bir alt kültür yaratmış, küreselleşme politikaları ile hızla yabancılaşan kültür piyasasına karşı kendilerini ifade edecekleri, dillendirecekleri ve seslerini duyuracakları bir alan açmışlardır (Gürbilek 2011). Uygulanan imar afları bu gecekondu bölgelerinin daha da yayılıp ve kalıcılaşmasına sebep olmuş, diğer yandan şehrin çeperlerinde üst ve orta sınıflar için yeni yaşam tarzına uygun lüks mimari ile kapalı site formunda yapılar çoğalmıştır. 1996 yılında kurulan Hafriyat Kolektifi yayınladıkları manifestolarında göçlerle birlikte oluşan melez kültür üzerine çalıştıklarını, şık ve steril ortamlara mesafeli durarak başka bir gerçekliğe baktıklarını, kentte dolaşmayı sürdürerek raslantısallıkla kent imgelerini ele geçirdiklerini ileri sürerler (Zeytinoğlu 2004). Emre Zeytinoğlu kolektifi "metropol gözlemcisi" olarak nitelendirir.

Kente yönelik artan müdahaleleri 90'lardan itibaren eserlerine konu edinen bir diğer sanatçı Canan Tolon'dan bahsedebiliriz. Yeryüzünün sayısal verilere indirgenerek şekillendirilmesi, inşaata özgü konstrüksiyonlar, bu konstrüksiyonların yarattığ doku hem imaj olarak desenlerinde hem de nesne olarak yerleştirmelerinde öne çıkar (Şekil 3 ve 4).

Küresel neoliberal politikalar kendi mekânsal rejimi gibi kendi kültür endüstrisini de yaratmıştır. Günümüzde bienal, festival ya da fuarlar gibi küresel kültür ve sanat etkinlikleri, siyasi strateji ve ekonomik beklentilerden, kentsel dönüşüm projelerinden ve küresel sanat piyasası ağlarından bağımsız düşünülmesi mümkün değildir (Yardımcı 2005). Türkiye'ye baktığımızda, kültür alanında uygulanan özelleştirme politikaları ile devletin karşılayamadığı açıkların özel sermaye gruplarınca kapatılmaya çalışıldığını görüyoruz. Bu da özellikle 1990'lardan itibaren kent hayatına etki eden hızlı bir kurumsallaşmayı beraberinde getirmiştir. 1987 yılından itibaren düzenlenmeye başlayan İstanbul Bienali'nin özellikle ilk edisyonlarında tanıtım ve saygınlık öğesi vurgusu değerlendirmelerde yer almıştır (Madra 2003). İlk bienallerden itibaren, tartışmalar genellikle sergi için seçilen mekanlar ve uygun sergileme merkezlerinin bulunmayışı, kentin çok kültürlü yapısı, yerel yönetimlerin yeterli destek ve önemi vermemesi, yer- 


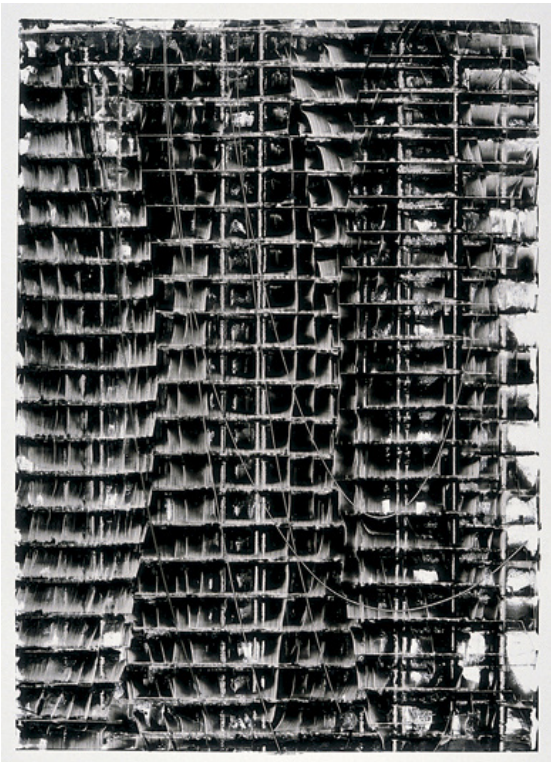

leşmeye başlayan küratör olgusu ve davet edilen yabancı küratörler üzerinde gelişmiştir diyebiliriz. Aynı zamanda bienaller için seçilen kavramsal çerçeve ve İstanbul temsili de tartışma konusu yaratmıştır. 4 . bienalin küratörü René Block İstanbul'daki bienal için İstanbul'un olayın merkezinde olduğunu, gerçekleşen bienalin öncelikle İstanbul için yapıldığını bienal kataloğundaki söyleşisinde ifade eder (Block 1995).

1980'lerden itibaren devletin sanat üzerindeki denetiminin gevşemesi, sanat dünyasının resmi kurumlara olan bağl111ğının azalması sanatçılara bir tür özgürlükler alanı sağlamıştır. Yurtdışı ile kalkan ekonomik sınırlar aynı zamanda bir bilgi patlamasına yol açmış, kuram kitaplarının çevirileri artmasıyla sosyoloji ile tanışılmış, yurtdışındaki kültür sanat tartışmaları ile eş zamanlılık sağlanmış, aynı zamanda bilgisayar, video kamera, televizyon gibi teknolojik aletlerin kullanılması geleneksel kalıplar içinde üretilen sanat algısını değiştirmiştir. Böyle bir kültürel ortamda gelişen güncel sanat ortamı ise 1990'lı y1llardan itibaren özellikle 2000'li yıllarda etkili olmaya başlamış; Batı sanat anlayışının bittiği, yerelliğin daha ağır bastı̆̆ 1 , temsiliyetten kaçan, sanat olan ve olmayanı kavramsalda eriten, bakışların ve malzemelerin çoğullaştığı refleksif sanat olarak kendini var etmiştir (Akay 2016). Sanatçı inisiyatifleri, kolektif projeler

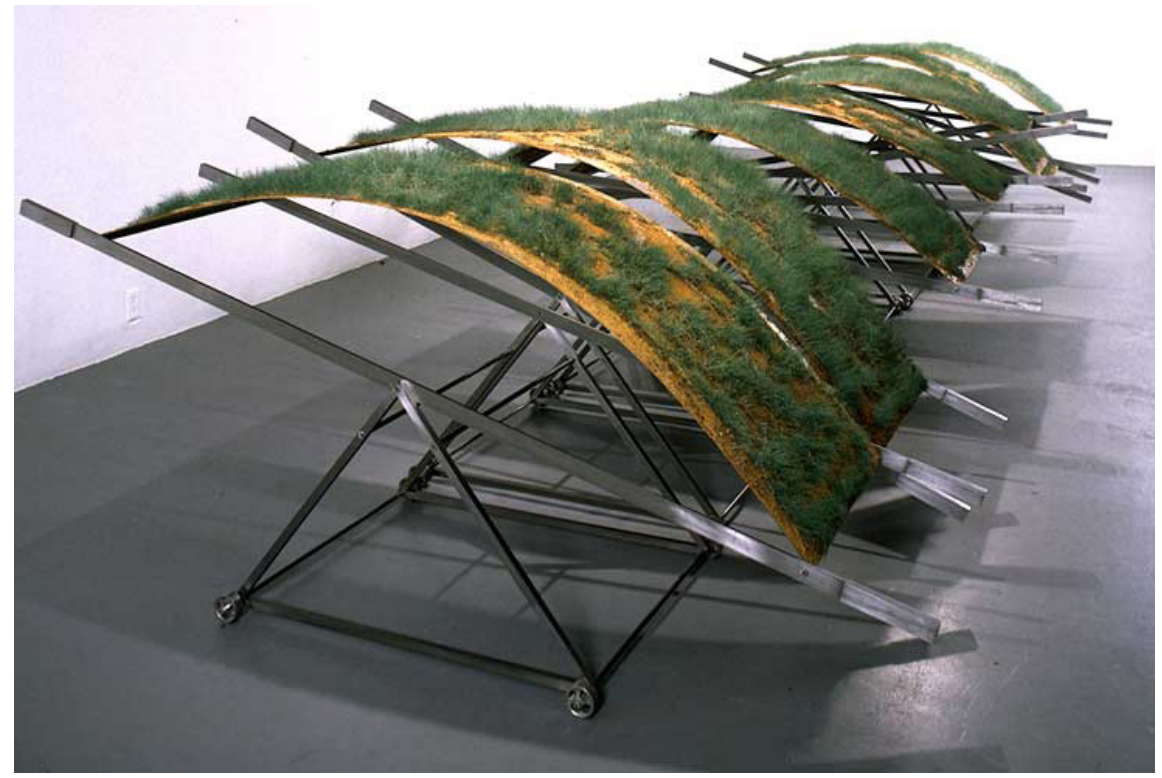

ve kente yayılan sosyal etkileşimli sanat pratikleri yine bu dönemden sonra ortaya çıkmıştır. Özellikle 2000'lerden itibaren görünürlüğü artan bu sanat inisiyatifleri; kendilerine özgü bir faaliyet alanı yaratma, kurumlardan ve aracılardan bağımsız, etkin bir şekilde sanatsal alana müdahale etme amacı ile güncel sanat ortamının mekan sorununa bir yanıt aradığı söylenebilir.

\section{0 - 2013 Yillart}

1999 Marmara depremi ve 2001 ekonomik krizi ile istikrarsızlaşan siyasi ortam 2002'de yapılan genel seçim sonucunda AKP iktidarı ile yeni bir döneme girer. Bu dönemde başlayan Avrupa Birliği müzakereleri ile İstanbul ön plana çıkmıştır. Büyük bir ekonomik dönüşüm ve yeniden yapılandırmalara ağırlık veren yeni hükümet inşaat sektörüne yatırımlarını arttırmış, hem işsizliği önleyerek ekonomik büyümeyi hem de alt ve orta kesimlerin barınma problemlerini çözmeyi amaçlamıştır. Toplu Konut İdaresi (TOKI) ve Özelleştirme İdaresi'ne sınırsız yetkiler verilmiş, Kanun'da tanımlı alanlarda her ölçekte imar planı yapma ve yaptırma imkanı tanınmış, konut dışında finans merkezi, otel, alışveriş merkezi gibi diğer fonksiyonlara ait projeler gerçekleştirmesinin önü açılmıştır (Kahraman 2013). Kamu arazileri üzerine yapılan inşaatlarda önemli bir aktör olan TOKİ, büyük inşaat şirketleri ile ortak konut

\section{Şekil: 3}

Canan Tolon, Isimsiz, 1997, mylar baskl üzerine siyah boya, $35 \times 28 \mathrm{~cm}$ (Sanatf̧ının izniyle).

Şekil: 4

Canan Tolon, Under Pressure, her biri 100 $\times 243 \times 61 \mathrm{~cm}, 1994$ (Sanatçının izniyle). 
üretimine gitmiş, yerli ve yabancı sermayenin desteğiyle kentsel dönüşüm projeleri başlatmıştır. 2011 yılında kurulan Çevre ve Şehircilik Bakanlı̆̆ı, devamında Yapı Denetimi, İmar Kanunu, Koruma Kanunu gibi düzenlemeler ve en nihayetinde kabul edilen Afet Yasası, sermaye güçlerine her türlü kolaylığı sağlayan, rant odaklı, planlamadan çok projeciliğe dayanan kentsel dönüşüm uygulamalarını birbiri ardına işleme sokmuş, İstanbul'u koca bir şantiyeye çevirmiştir (Uşaklıgil 2014).

Yeni kent merkezi olarak şekillenen Levent - Maslak aksında 2001'de açılan Proje4L Elgiz Çağdaş Sanat Müzesi, Vasıf Kortun yöneticiliğinde Yerleşmek sergisi ile açılışını yapmış, mekânsal ve toplumsal dokuda değişim, ayrışma/parçalanma, yerel dinamikler ve özellikleri, şehir merkezinin başka faaliyetler için boşaltılması sorunsallaştırılmıştır. Sergide yer alan Oda Projesi kolektifi müze ve içinde bulunduğu Gültepe mahallesi arasında aracılık rolü üstlenmiş, müzenin bir buluşma noktası olma fikrinden yola çıkarak, mahalleliler ile müzeyi birleştirmeyi hedeflemiştir. Müzenin içinde olmak yerine, mahalleden bir yer kiralayıp, bu mekanı çeşitli etkinliklerle katılımcılara açarlar. Mahalleli çocuklarla sergi turlarının yanı sira mahallelinin getireceği nesnelerden oluşan bir sergi tasarlarlar (Kamhi 2013) (Şekil 5).

2005 yılında İstanbul temal1 9. İstanbul Bienali'nin küratörleri Charles Esche ve Vasıf Kortun, bienalin, şehri küresel kapitalizme satmak için bir araç ya da aralarında rekabet olan pazarlanabilir şehirler yarışında bir marka olarak değil; gerçek, yaşanmış bir yer olarak konumlandırmak, onu sakinlerine ve başkalarına farklı bir bakışla sunmak olduğunu belirtirler. Küresel bir sergi örneği olarak bienalin sanat dünyasının küresel genişlemesini yönlendirdiğini; sosyalizmin çöküşü ve küresel ekonomik büyümeyle beraber sanatçıların kendilerini ve pratiklerini beslemek üzere serbest piyasaya erişebilir hale geldiğini teslim ederler. Bunun bir sorun olmadığı$\mathrm{n} 1$, asıl tehlike olarak yeniden üretimden kaynaklanan homojenleşme, bienallerin birbirine benzemeye başlaması, serbest pi-

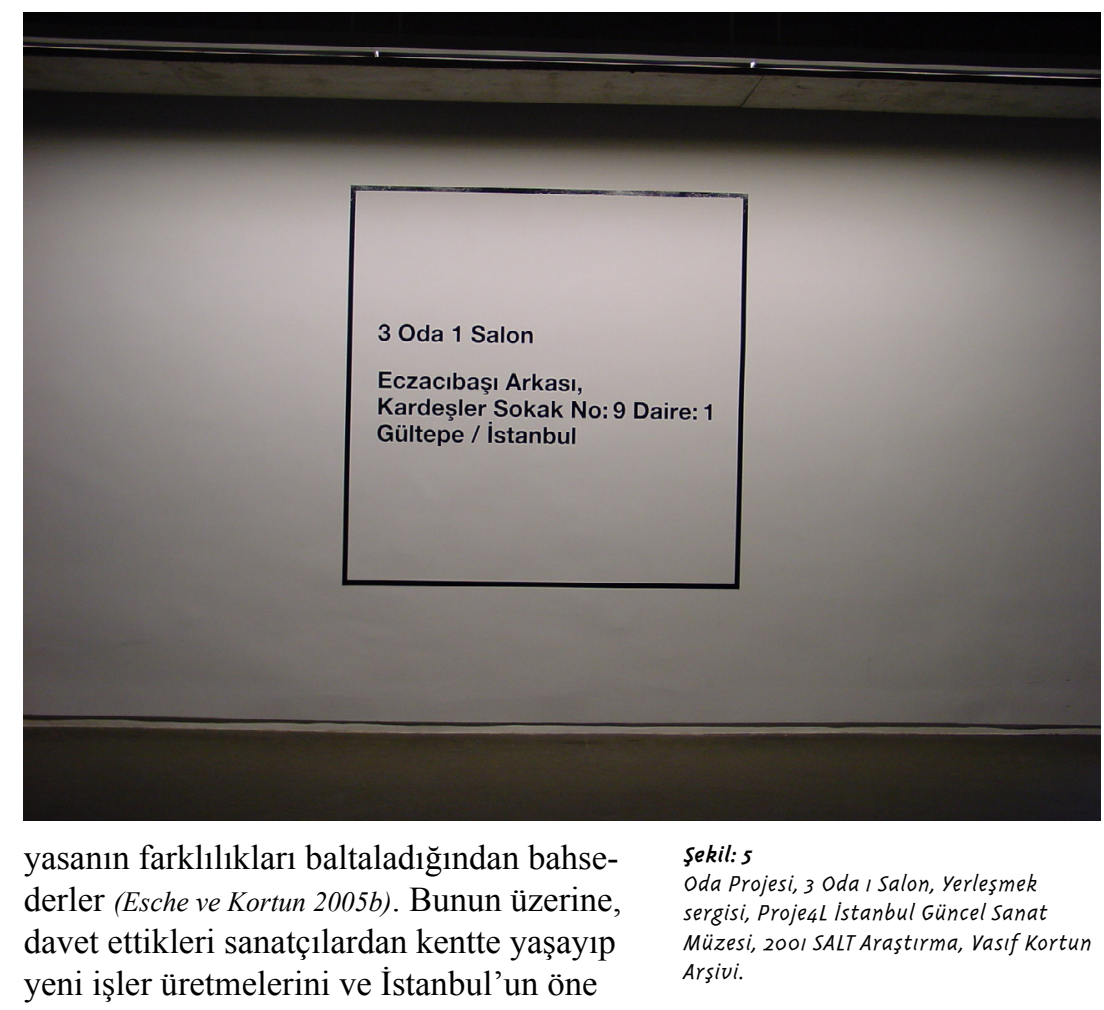

çıkan özelliklerine 1şık tutmak istediklerini aktarırlar. Bu bienalde alışılmışın dışında tarihi yapılarda sergilemeler birakılıp sergiler Beyoğlu - Galata bölgesine kaydırılır ve hararetli bir dönüşümden geçen kente başka bir gözle bakılması amaçlanır (Esche ve Kortun 2005a).

2005 y1lında 5366 say1lı "Yıpranan Tarihi ve Kültürel Varlıkların Yenilenerek Korunması ve Yaşatılarak Kullanılması Hakkında Kanun" ile mahalle mahalle kentsel dönüşüm furyası başlamış olur. Bu kanunun ilk olarak yürürlüğe girdiği Neslişah ve Hatice Sultan mahalleleri, kamuoyunda bilinen ismiyle Sulukule, belki de toplumsal aktörlerin en fazla bir araya gelip çalışmalar yürüttüğü mahalle olduğu söylenebilir. Hakkında önce yenileme alanı ilanı, ardından acele kamulaştırma kararı çıkartılarak yaklaşık 5000 kişi yerinden edilmiştir. Buna rağmen Sulukuleliler mahallelerini terketmeyip, yıkılan evlerin yanındaki sokaklara yerleşmişler, kurulan Sulukule Platformu kapsamında direnmeye devam etmişlerdir. Mahalleye dayatılan dönüşüm sürecini sorgulayan birçok aktivitenin içerisinde 2009 yılında Hafriyat Karaköy'de düzenlenen Suluku- 
le sergisi öne çıkar (Sulukule Günlüğü 2019). Sergi süresince mücadeleye katılan ve katılmayanlar bir araya gelmiş, ortaklaşan pratikler üzerinden diğer mahalle örnekleri ve mücadele süreçleri tartışılarak mahalle, mücadele, yerellik, kent, İstanbul, görsel üretim ve temsiliyet, hukuk, etnik kimlik, alternatif ekonomiler, geçmiş tarihsel mücadele örnekleri gibi konular ve deneyimler etrafinda geniş bir paylaşım ve etkileşim ortamı kurulabilmiş̧î (Tan 2013) (Şekil 6).

Hafriyat Kolektif üyesi Nalan Yırtmaç 2008'de gelen bir davetle mahalleli ile tanışıp çalışmaya başlamış, çocuklar ile atölyeler yapmış, mahalleli kadınlara ekonomik destek olması amacıyla Kader Kısmet Atölyesi'nin kurulmasında yer almıştır. Sanatçı daha sonra bu deneyimi benzer bir dönüşüm sürecine giren Tarlabaşı'nda Göçmen Mutfak'ta çalışarak sürdürmüştür. Bir çalışmasında Fener Balat gibi farklı mahallelerin restorasyon öncesi çektiği bina fotoğraflarıyla bir kolaj oluşturmuş, yıkıma karşı bir araya gelenleri dev bir kahramana benzetmiştir. Sanatçı kentsel dönüşüm tehlikesi altındaki mahalleleri gezerek çektiği fotoğraflardan çalışmalarını geliştirmiştir (Şekil 7 ve 8).

Sulukule'de çalışmış bir diğer sanatçı Halil Altındere'dir. Sulukule Platformu'nun yürüttüğü çocuk atölyesinden Veysi Özdemir, Asil Koç ve Burak Kaçar'dan oluşan Tahribat-1 İsyan ve bir diğer rap sanatçısı Fuat Ergin ile birlikte çektikleri Wonderland isimli video mahallede yaşanan kentsel dönüşümü odağına alır. Alt kültür estetiği ve hiphop tarzında yazılmış sözleri ile bir müzik klibi formunda şekillenen video, Sulukuleli gençlerin mahallelerini ellerinden alan devlet güçlerine karşı direnişini anlatır (Şekil 9).

Hafriyat Kolektif üyelerinden Hakan Gürsoytrak kente bakışı, üst üste yı̆̆ılmış bina ve beton katmanlarının altına saklanmış geçmişi görmek olarak tanımlamaktadır. Bugünün ve bu geçmiş üzerine inşa edilen mimari ve zihniyetin böylece görünür kılınacağını tarif eder. Alt yapısız asfaltın politik zihniyetin bir göstergesi olabileceği gibi, bitmeyen kazı, inşa ve hafriyatın ha-

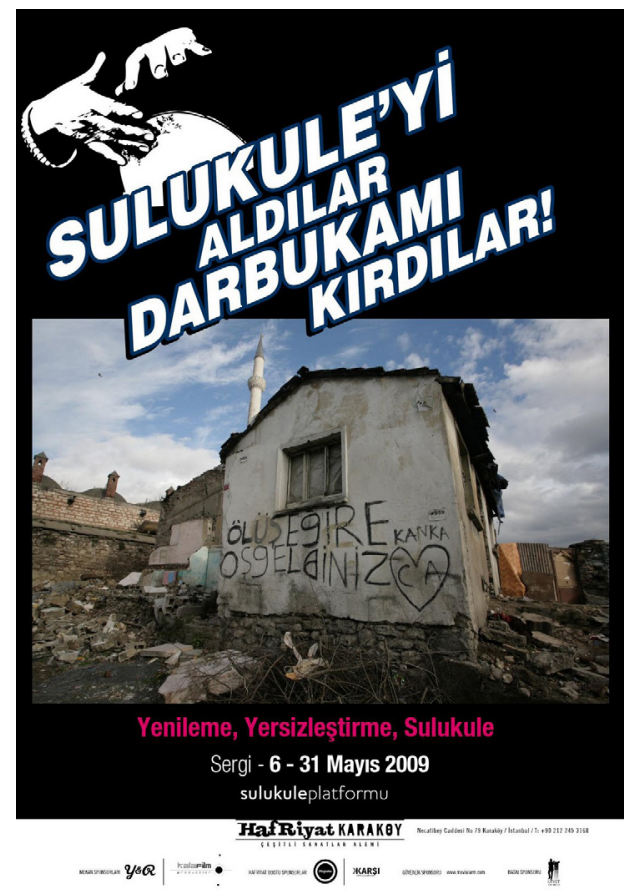

yatlarımızın gerçekliği olarak görmektedir (Acar 2007) (Şekil 10).

Yine kolektif üyelerinden Antonio Cosentino'nun peynir tenekelerinden yaptığ kent tasarımları, küreselleşmenin yarattığ1 tüketim kültürünün kentleri tüketilen bir meta yaptığı kadar, kentlerinin içini de tüketilen metalarla doldurarak şekillendirmesini anımsatır. Sanatçı günlük hayatın içinden, kişisel hafızasından ya da şehrin görsel kültüründen beslenerek bir tür arşivci gibi çalışır, tenekelerden

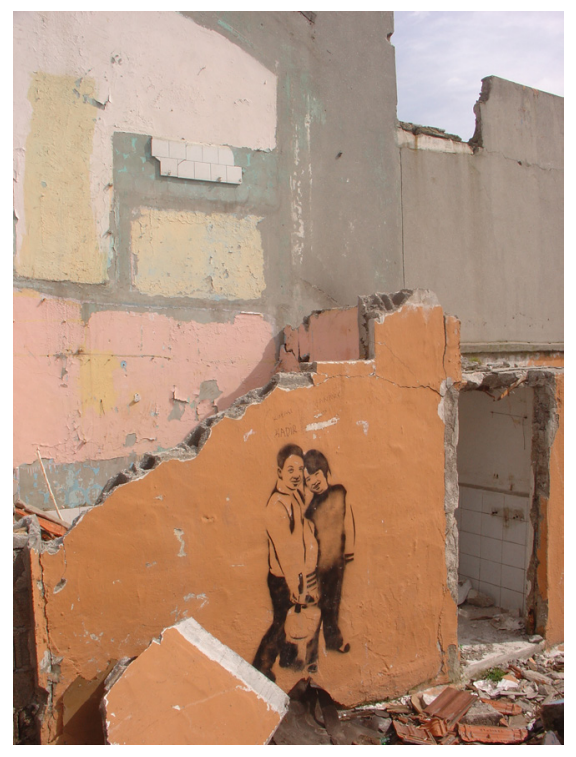

Şekil: 6

Hafriyat Karaköy'de gerçekleşen sulukule sergi afişi, 2009 [http://sulukulegunlugu. blogspot.com]
Şekil: 7

Nalan Yırtmaç, Sulukule, 2008 (Sanatçının izniyle).

Şekil: 8

Nalan Yırtmaç, yıkılan mahallelerin, yerinden edilenlerin gücü adına duvar üzerinde grafitti, DEPO, 2010 (Sanaţ̧ının izniyle).

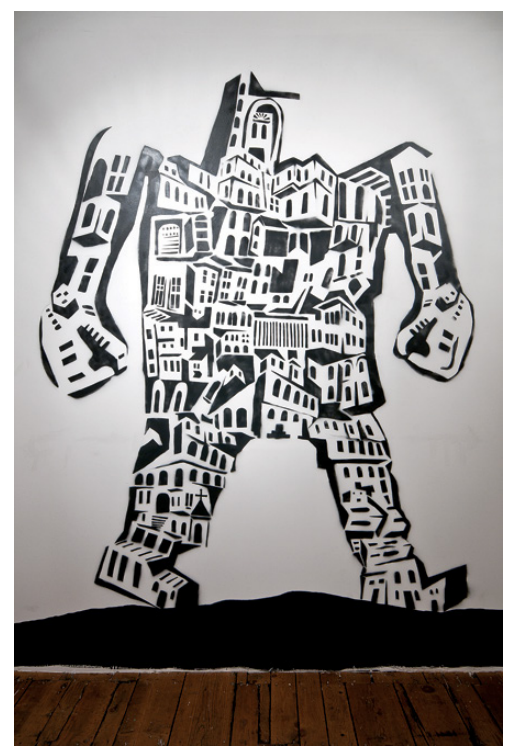




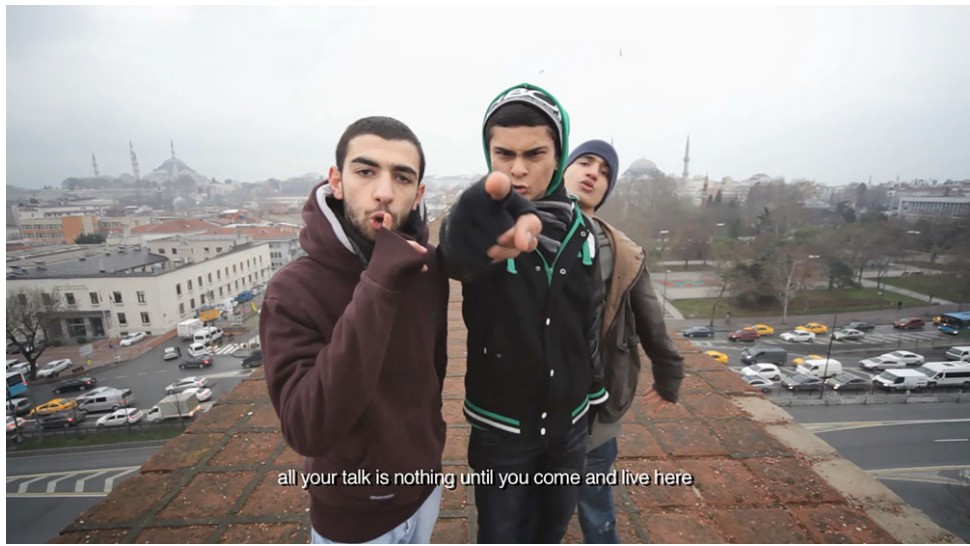

Şekil: 9

Halil Alt indere, Wonderland, HD video, 8'25', video görseli, 2013 (Sanatçının izniyle).

şekil: 10

Hakan Gürsoytrak, Operasyon Yetkililer Çay içti, $148 \times 200 \mathrm{~cm}, 2006$ (Sanatçının izniyle).

Şekil: II

Antonio Cosentino, Teneke şehir, 2009-2013 (Sanaţ̧ının izniyle).

Şekil: $\mathbf{1 2}$

Neriman Polat, Mülk Allahındır, değişebilir boyut, 2007/2018 (Sanatçının izniyle). bir kent maketi oluşturur. Aynı yöntemle kent içi ulaşım araçlarını da ele alan sanatçı, özellikle gemi imgesi üzerinde durarak Marmara Denizi'ne odaklanır. Kentin karasal sınırları kadar kıyı şeridi de sürekli dönüşüm içerisindedir ve buna bağlı olarak kentlinin deniz ile ilişkisi belirlenir. Burada yer verilen çalışmanın çıkış noktası eski bir Ermeni semti olan Kumkapı'nın demografik, etnik ve mekânsal dönüşümüne işaret eder (Şekil 11).

Kentten gidenler kadar, kente göç edenler, sürekli artan nüfusuyla İstanbul'un bir gerçekliği olarak sanatçılar tarafindan sorgulanır. Yeni gelenler kendi kültürünü de beraberinde getirir ve yerel olanı dönüştürür. Ucuz cephe kaplama tekniklerinden mozaik, sanatçı Neriman Polat'ın kentte izini sürdüğü bir yapı malzemesidir. Bu mozaik kaplama cephe kaplaması olmanın ötesinde, işleme motifler, yöresel ve dini göndermeleri olan cümleler ve özlü sözlerle, yeni kentlilerin kendilerini ifade

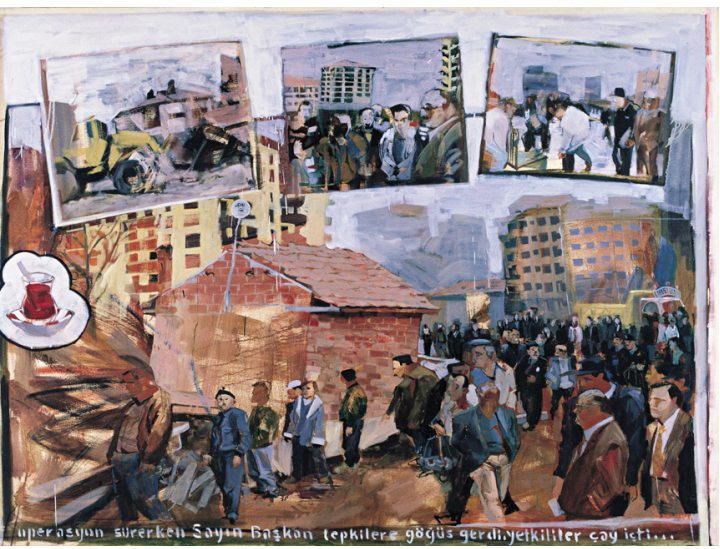

ettikleri alternatif bir mecraya dönüşür. Sanatçı çalışmalarında bu kitlelerin geliştirdiği görsel dili kaydeder ve yeniden uygular (Erbaş ve Leicht 2008) (Şekil 12).

Hafriyat kolektif üyesi Neriman Polat, kendisiyle yapılan söyleşide gruba katılmasıyla İstanbul, sokaklar, sokağın dili, mahalleler, kaldırımlar, dış cephe gibi her şeyin ilgi alanına girmeye başladığını aktarır. Henüz kentsel dönüşüm kavramını kullanmasalar da 1980'lerden itibaren artan yoğun dönüşümün farkında olduklarını vurgular ve bunun sanatsal ifadesini aradıklarını belirtir (Gecikmez 2019) (SSekil 13). 2007 yılında İstanbul, 2010 Avrupa Kültür Başkenti olacağı ilan edilir. Projeyi yürütmek adına kurulan İstanbul 2010 Avrupa Kültür Başkenti Ajansı, Koordinasyon Kurulu (Başkan olarak dönemin devlet bakanı Hayati Yazıcı, dönemin Kültür ve Turizm Bakanı Ertuğrul Günay, dönemin İstanbul Büyükşehir Belediye Başkanı Kadir Topbaş), İlçe belediye başkanları, kaymakamlar, öğretim üyeleri, sivil toplum temsilcilerinden oluşan Danışma
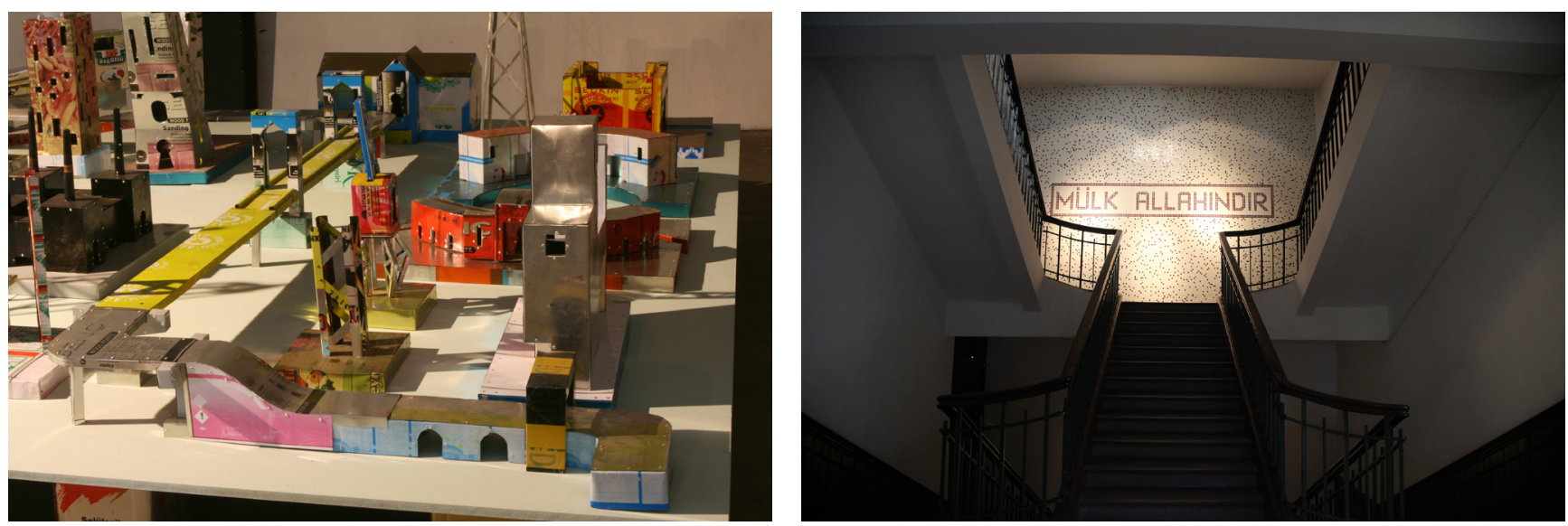
Kurulu ve kararları alan Yürütme Kurulu (Başkanlığı Sevket Avkadiç, sivil toplum kuruluşları temsilcileri, ITO, ISO temsilcileri, Valilik temsilcisi, IBB temsilcisi gibi farkl kurum ve temsilciler) olarak yapılandırılır. Bu bakımdan devlet, özel sektör ve Stk'ların ilk kez bir araya geldiği organizasyon olduğu söylenebilir. Yayınlanan program kataloğunda, İstanbul'un kültürel zenginliği, Avrupa ve Asya arasındaki köprü konumu, küreselleşen ekonomisiyle mega kentleşmesi, Avrupa ile bütünleşme ve kültürel bir diyalog kurma konularına dikkat çekilir. Bu anlamda gerçekleşecek kültür ve sanat etkinliklerinin, dışlanmışlık ve ayrışmanın önüne geçerek kentteki dönüşümü kentlilerin medeni ve bir arada yaşama ihtiyaçlarına cevap verecek bir istikamete doğrultmay1 amaçladığ 1 belirtilir (İstanbul 2010 Avrupa Kültür Basskenti 2010 Programı 2010). Genel olarak bakıldığında İstanbul 2010 Avrupa Kültür Başkenti projesi, İstanbul'un Avrupa'ya eklemlenmesi adına büyük bir adım olarak görülmüştür. $\mathrm{Bu}$ anlamda eksikliklerin giderilmesi, gerekli rehabilitasyonun gerçekleşmesi, dönüşümlerin hızlanması adına projeler gerçekleştirilmiştir. Gerek yurtiçinde gerekse yurt dişında İstanbul'un tanıtımı gerçekleşmiş, bu şekilde kente yatırımcılar davet edilmiştir. Proje kapsamında kentin sorunlarına dair kalıcı çözümler getirmek de amaçlanmıştır. Fakat günümüze gelindiğinde projenin sürekliliğinden söz etmek mümkün gözükmemektedir.

Yıllar içerisinde mahalle ve mahallelilerle edindikleri deneyimi farklı projelere aktaran Oda Kolektifi, 2008 - 2010 yılları arasında, Philipp Misselwitz ve Nikolaus Hirsch tarafindan davet edilerek, Gülsuyu - Gülensu mahallesinde, mahallelinin yönlendireceği alternatif kentsel dönüşüm planı için "Kültürel Aracılar" adlı projeyi yürütürler. Proje, 2010 İstanbul Avrupa Kültür Başkenti etkinliklerinin merkezde yoğunlaşmasına eleştirel olarak kent merkezi saplantısını sorgulamış, periferideki kültürel kurumsallaşmayı araştırmış, mahalledeki mevcut kültür olgusu nasıl pekiştirilir, yeni format ve platformlarla nasıl geliştirilir, böyle bir altyapı kültürel altyapı ve kapsayıcı kentleşmeyi nasıl

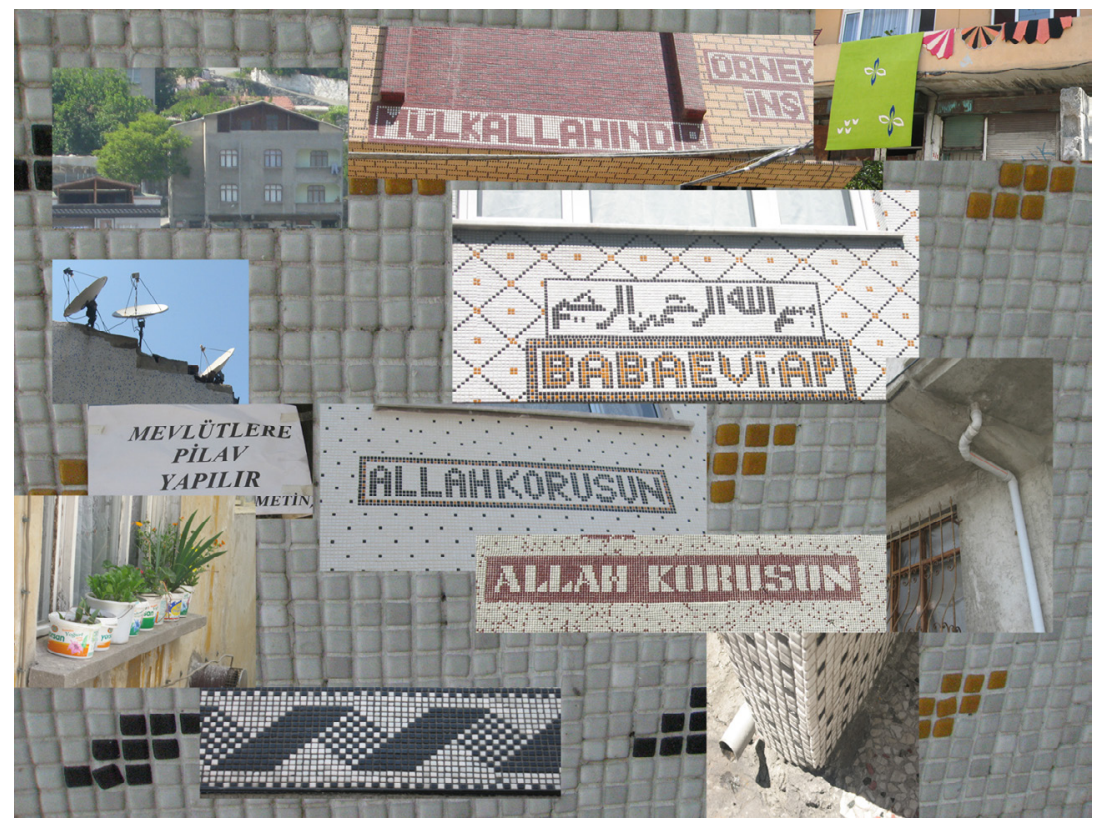

destekleyebilir soruları etrafında çalışma- sekil: 13

larını gerceklestirirler (Hirsch ve Misselwitz Neriman Polat, sehir Serisi I, fotoğraf, $100 x$ 2019). Farklı disiplinlerden davet edilen araştırmacı, akademisyen, öğrenci, sanatçı, yazar, mimar, plancı, aktivist gibi kişiler bir araya getirilerek atölyeler düzenlenmiş, farklı aracılık biçimlerini araştırılmıştır. Proje; hikayeler, nesneler ve örgütsel modeller yoluyla çarpıcı kentsel değişim süreçlerinin izini sürerek ve varlıklarını ispatlayarak "kent hakkı" için verilen siyasi mücadeleyi güçlendirmek adına anlatıları ve nesneleri seferber etmeyi amaçlar (Hirsch ve Misselwitz 2019). Yılların mahalle sakini olan Erdoğan Yıldız projenin mahallenin iç ilişkilerini yeniden keşfettiğini, gerçekleşen gezi ve etkinliklerin ufkunu açtığını, sözlü tarih çalışmalarıyla mahallenin hiç bilmediği yönlerini ortaya çıkardığını paylaşır. Aynı zamanda, sanat ve sanatçının yaratıcılığı ile yerel örgütlenmenin bağı kuvvetli kurulabilirse sadece mahalleli için değil sanatçı için de özgürleşmeye yol açacak önemli bir anahtar olduğunu vurgular (Ylldiz 2011) (Şekil 14).

2010 y1lında bir diğer kentsel dönüşüm alanı ilan edilen Kadıköy ilçesine bağlı Fikirtepe Mahallesi'nde belediyenin gerekli yasal düzenlemeleri yaptıktan sonra inşaat şirketleri ve malikleri baş başa bırakması, firmaların güven ve teminat vermemesi sürecin tıkanmasına sebep olmuştur. 
Şekil: 14

Gülsuyu - Gülensu Dükkanı, 2010 (Oda Projesinin izniyle)
Şekil: Is

Ahmet Ö̈̆̈̈t, Her Çeşit Haz Mekanları - Fikirtepe Mahallesi, yerleștirme, 2014 (Sanatçının izniyle).

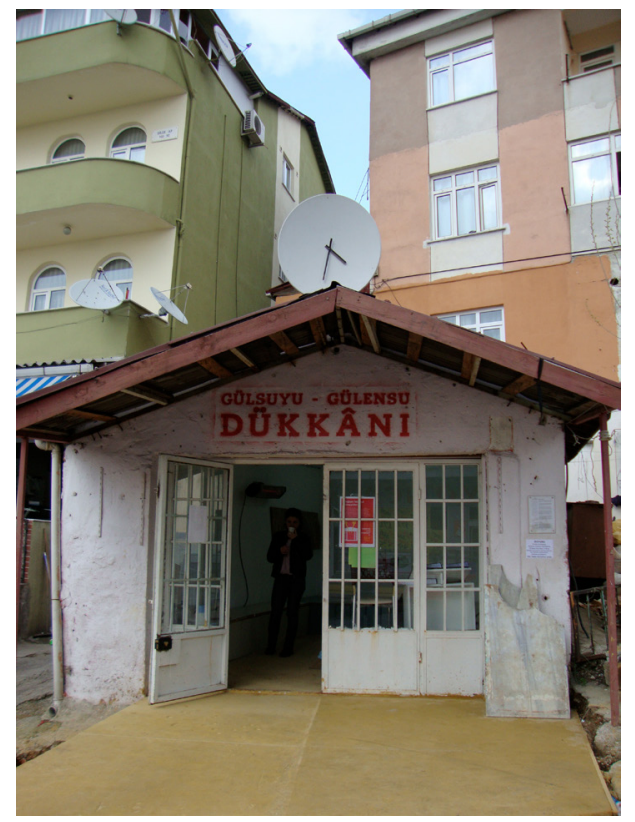

Artan şikayetler ve kutuplaşmalar sonucu projeler durdurulmuş çıkan Afet Yasası ile çözüm yaratılmaya çalışılmıştır. Bu süreç içerisinde 31 dönümlük arazinin ortasında çevresindeki binaların tümünün yıkıldığ 1 için tepeye benzeyen bir toprak parçası üzerinde kalan iki katlı evin fotoğrafı medyada büyük yankı uyandırmıştır. Sanatçı Ahmet Öğüt bu evi bir tür kentsel dönüşüme direniş olarak okuyup üç boyutlu bir heykel maket olarak yeniden ele alır (Şekil 15).
2016 y1lında gerçekleştirdiğim Master Plan adlı resim Zaha Hadid'in 2006 yılında, IMP (Istanbul Metropoliten Planlama ve Kentsel Tasarım Merkezi)'nin organize ettiği yarışma kapsamında tasarladı̆̆ 1 Kartal projesini konu eder. Hadid, bilgisayar teknolojisinin tüm olanaklarını kullanarak, mimarlık tarihinde kendi üslubuyla öne çıkmıştır. Sonrasında yıldız mimarlar arasında anılarak, imzasını attığı her mekânsal tasarım dünya üzerinde ses getirmiştir. Hadid'in dijital ortamda hazırladığı kentsel dönüşüm projesi “Kartal Master Plan", bölgede yaşayan insanların yaşam pratikleri göz önüne alınmadan tasarlanarak, sermaye odaklı uygulamalar üzerinden tanımlanan bir kent kimliğini gözler önüne serer. Bu projede ne semtin kendi sakinlerinin ihtiyacina yönelik bir yapılaşma, ne de ortak hafıza ve sembolik değerlere sahip mekanların korunması söz konusudur. Nitekim yerel aktörlerin açtığı davalar sonucu projenin uygulaması durdurulmuştur. Hadid' in kent manzarası simülasyonu gerçeküstücü bir yaklaşımla yeniden yorumlanan bu resimde, parçalanmış beden kesitleri pornografik bir dönüşüme işaret eder: iktidarın güdümüyle bir fetiş nesnesi haline gelen inşaat sektörüne, bedenin pornografik dönüşümüyle yanıt verilir (Gecikmez 2019) (Şekil 16). Tüm bu mahallelerin dönüşümünde baş aktör olan TOKİ de çalışmaların konusu

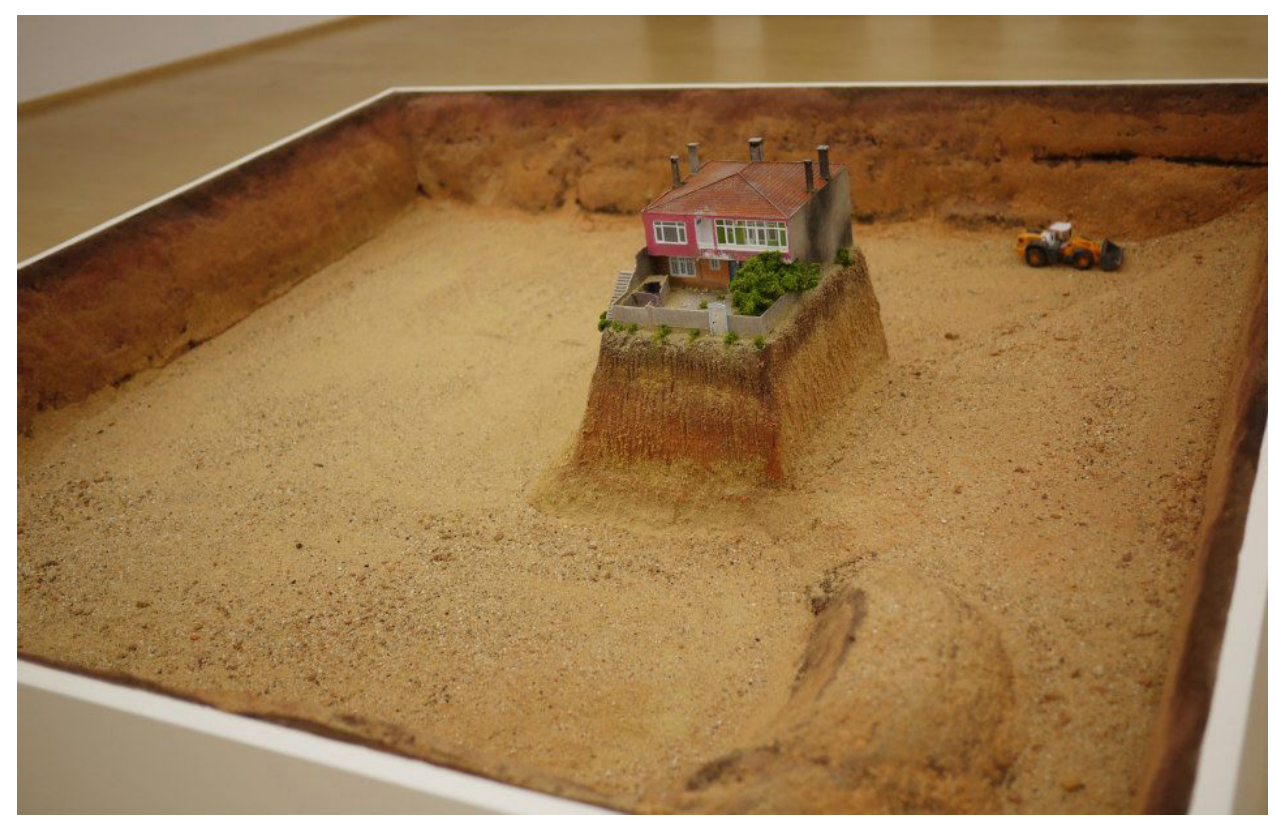




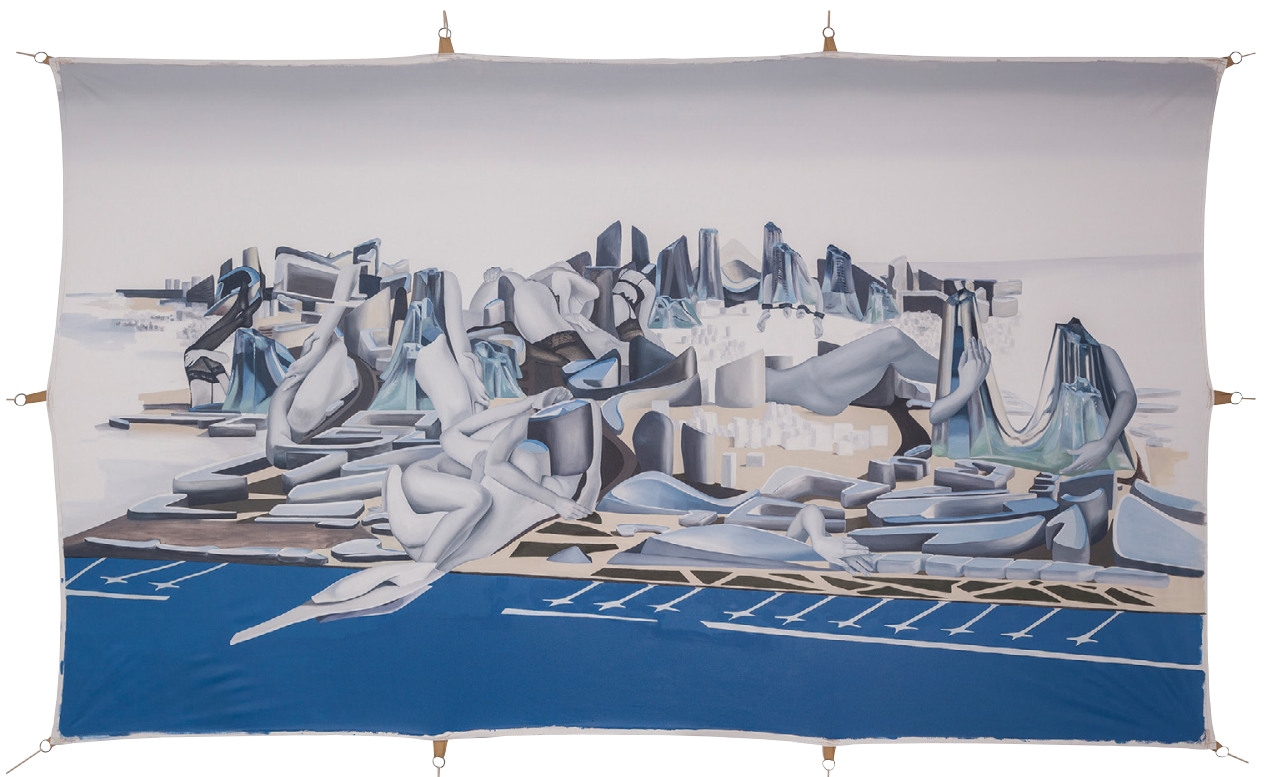

haline gelir. Neriman Polat; Nalan Yırtmaç ve Fulya Çetin ile Tuzla ve Halkalı'daki TOKİ konutlarına gittiklerinden, orada yaşayanlar ile röportajlar yapıp belgelediklerinden bahseder (Gecikmez 2019). Daha sonra bu deneyimi davet edildiği bir sergi kapsamında, Galata'daki bir sergi salonunu emlak ofisine çevirerek kullanır. Özdönüşüm Emlak adlı bu yerleştirme ev fiyatları, borç bilgileri, insanların yaşadıkları sıkıntıların aktarıldığı röportajlar, tabelası, vergi numarası ile tam bir emlak dükkanıdır. TOKİ konutlarında yaşanan hayatı en iyi bir emlakçının anlatabileceğini vurgular. Aynı dükkanı daha sonra davet edildiği Çanakkale Bienali'nde oranın yerel bilgilerinden hareketle tekrar açmıştır (Şekil 17).

2012 yılında İKSV tarafindan 1. İstanbul Tasarım Bienali düzenlenmeye başlanır. İki ayrı sergi olarak tasarlanan bienalin küratörleri Emre Arolat ve Joseph Grima'dır. Arolat'ın İstanbul Modern'de gerçekleşen Musibet isimli sergisi isimli sergisi, bugünün İstanbul'unu mimari tasarım ve kentsel dönüşüm çalışmaları açısından irdeleyen ve sorgulayan 95 tasarımcı ve mimarın 30'un üzerinde projesini bir araya getirir (Mimarizm 2012). Bu projelerden biri de mimarlık kökenli sanatçı Ali Taptık'ın Osmanbey'e Bakmak adlı projesidir. Taptık, süregelen doktora çalışması olarak bu projede semtin yıllar içinde değişen sosyo ekonomik yapısını inceler. 1970'lerden itibaren tekstil ürünlerinin üretim ve ihracat merkezi olan semt günümüzde popülasyonu ve yapısında büyük bir dönüşüm geçirmiş, otellere ve ticaret merkezlerine dönüştürülen yapılar Afrika, Orta Doğu ve Doğu Avrupalı misafirleri konuk etmektedir. Taptık hem fotoğraflarıyla hem de mimari çizim ve arşivlerle Osmanbey'deki bu dönüşümün nedenlerini günümüze sızan katmanlarda araştırmıştır (Tapttk 2019). Sanatçı aynı zamanda Yedikule Bostanlarını Koruma Girişimi'nde yer alarak, burada Yedikule Bostanları'nı verimli bostan toprakları, bostancısı ile bir bütün olarak
Şekil: 16

Eda Gecikmez, Master Plan, Tuval üzerine yağlı boya, $180 \times 300 \mathrm{~cm}, 2016$ (Sanatçının izniyle).
Şekil: 17

Neriman Polat, Özdönüşüm Emlak Çanakkale subesi, Yerleştirme, 2012 (Sanaţ̧ının izniyle).

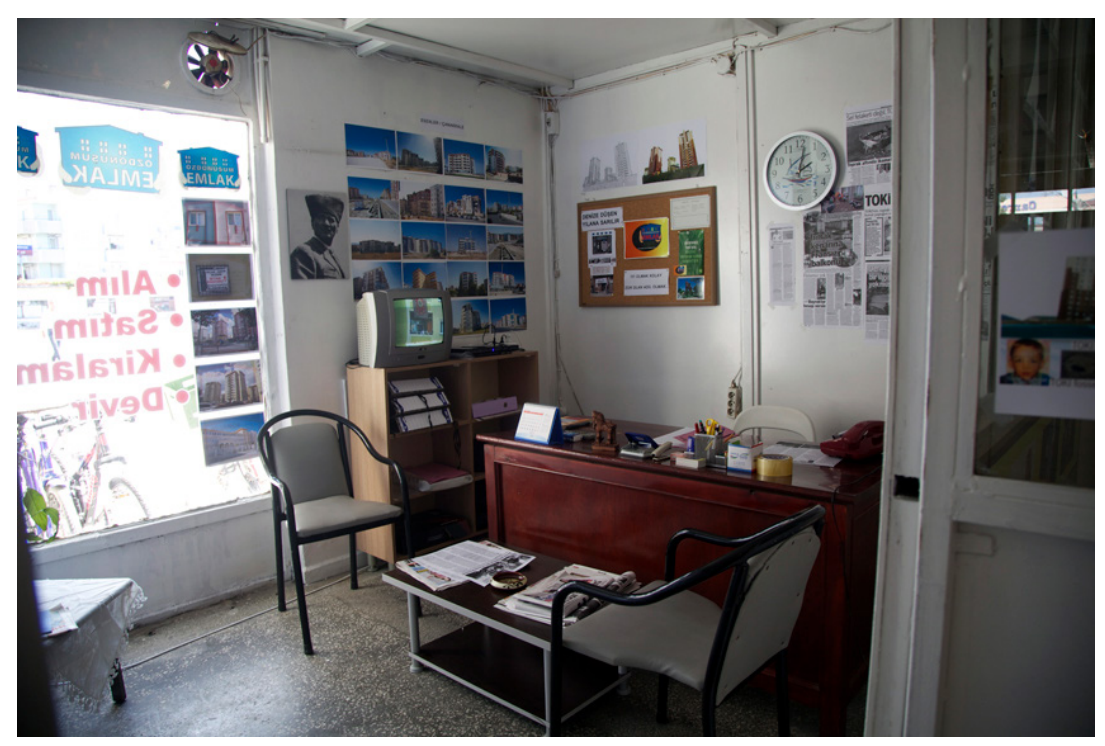




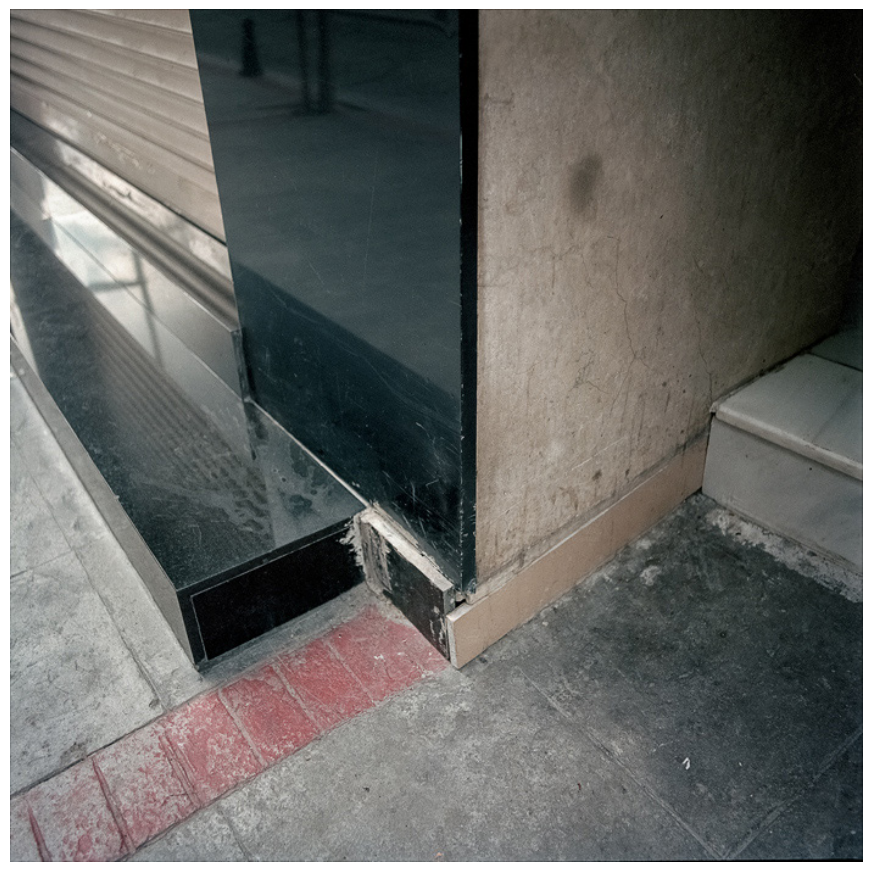

Sekil: 18 ve 19

Ali Taptık, Osmanbey'e Bakmak, 2012 (süregelen doktora çalışması, ITÜ FBE, Mimari Tasarım Programı, Sanatçının izniyle).
2014 yulinda "örgüt kurmak ve yönetmek" suçlamasıyla açıllan Gezi Parkı Davası tüm sanikların beraatıyla sonuçlanmıs; buna rağmen 2019 yılında tekrar açılmıştır. Saniklardan Anadolu Kültür A.ş. Yönetim Kurulu Başkanı Osman Kavala üç yılı askin hala daha tutuklu bulunmaktadir. 2016 yilinda Yurtta Sulh Harekatı adiyla bir askeri darbe girişimi olmuş, iki yıl olağanüstü hal uygulanmış, ihraçlar, tutuklama ve gözaltılarla yeni bir devlet yapılanmasına gidilmiştir. 2018 yilında Aurupa Parlamentosu Türkiye'ye yapılan Aurupa Birliği yardımlarında kesintiye gitmiştir. Buna gerekşe olarak "demokrasi, insan hakları ve hukuk devleti alanlarinda ilerleme kaydedilmemis olması" gösterilmiststir (Birgün 2018) Büyük bir intişamla hayata geçirilen mega projelerin ekonomiyi zarara uğrattı̆̆ı anlaşılmıştır (artı gerçek 2019) ama hala daha Kanal Istanbul Projesi için çalışmalar sürdürülmektedir. koruyacak sürdürülebilir bir proje geliştirmek için çalışmıştır (Şekil 18 ve 19).

\section{3 ve sonrast}

2011 genel seçimlerinde AKP'nin seçim propagandası olan 'çılgın projeler' siyasi güç elde etmek için her yolu mübah gören hegemonik tavrı toplumsal - siyasal mücadeleleri de arttırmıştır. Son 10 yıllık süreçte kapitalist kentleşme mücadelesi TMMOB'a bağlı birçok meslek odası, bazı sol - sosyalist siyasi partiler, Toplum İçin Şehircilik Hareketi - İMECE, Anadolu'yu Vermeyeceğiz, Karadeniz İsyandadır gibi örgütlenmeler olarak karşımıza çıkar (Penpecioğlu 2017). Şüphesiz bunun doruk noktasını Gezi Parkı direnişi oluşturur. 2013 yılı baharında kent merkezinde tek kalan yeşil alana Topçu Kışlası yapılmak üzere Gezi Parkı'na müdahale edilmesi tüm ülkeye yayılacak protestoları başlatır. Gezi Parkı direnişinin, kentsel dönüşüm projeleri ile betona ve sermayeye teslim edilen yaşam alanlarını korumanın yanı sıra gittikçe muhafazakarlaşan iktidara dair hoşnutsuzluğun bir ifadesi olduğu söylenebilir.'

Benzer şekilde kültür kurumlarının kendilerini neoliberal fonlama politikaları çerçevesinde şekillendirmesi ve küresel sermayeye daha fazla bağımlı oluşu bir çok eleştiri ve protestolara hedef olmaktadır.
Bu anlamda 2007 yılından itibaren bienalin ana sponsoru haline gelen Koç Holding bu tartışmaların hedefi haline gelir. $\mathrm{Bu}$ protestoların en akılda kalanı, 2011 yılında gerçekleşen 12. İstanbul Bienali'nin açılışında Koç Holding' in kurucusu ve sahibi Vehbi Koç'un 3 Ekim 1980'de Kenan Evren'e 'Emrinize amadeyim' diye bitirdiği mektubunun Kamusal Sanat Laboratuvarı tarafından bienal açılışına gelenlerle paylaşılmasıdır: "Unutturmak iktidarın en büyük silahıdır. Ama biz o isimleri hiç unutmadık. Ne insanca yaşamak için bedel ödeyenleri ne de yaşamı pazarlamak için can alanları. Gerçekleri gün yüzüne çıkarmak için, üzerindeki yaldızı çekinmeden KAZIYINIZ. Göreceğiniz bu ülkenin geçmişi, bugünü ve geleceğidir." (Kamusal Sanat Laboratuvart 2011).

Gezi Parkı eylemlerine denk gelen 13. İstanbul Bienali'nin kavramsal çerçevesi siyasi bir forum olarak kamusal alan fikri şeklinde olmasıyla gündemdeki tartışmalarla örtüşmüştür. Nitekim kavramsal metninde; mekansal - ekonomik adaletten, sınıfsal eşitsizlikten, toplumsal hareketlerden, sivil haklardan, aktivizmden, kentsel dönüşümden, kamusal alanlardan bahseden 13. bienal de (13B 2013), parçası olduğu neoliberal kültür endüstrisi bağlamında protesto edilmiş ve de eleştirilmiştir (İmece 2013). 
Gündemdeki Gezi protestoları nedeniyle işleyiş biçimini değiştiren bienal; kamusal alanda yer almaktan vazgeçip, kapalı sergi mekanlarına uyarlanmış, daha çok İstanbul ve gündemdeki tartışmalara özgü projeler sergilenmiştir (Erdemci 2014).

13. İstanbul Bienali'nde yer alan ve hala daha devam eden projelerden biri olan "Iki Deniz Arası" İstanbul'un tehditkar dönüşümünü yürüyerek deneyimlemeyi önerir. İstanbul'un kuzeyinde yer alan, kentin oksijen kaynağı ve türlü canlıya ev sahipliği yapan Kuzey Ormanları'nı katlederek gerçekleştirilen İstanbul Havalimanı ve Yavuz Sultan Selim Köprüsü'ne ek olarak Cumhuriyetin 100. Y1lına atıfla 2023 hedefi ilan edilen "Çılgın Proje" Kanal İstanbul'un yapılması planlanmaktadır. Karadeniz'i Marmara Denizi'ne bağlayarak bir kanalın açılmasına dayanan bu proje $50 \mathrm{~km}$ uzunlukta, $25 \mathrm{~m}$ derinlikte ve 150 m genişlikte olması öngörülmüştür (Logie ve Morvan 2017). Sanatçı Serkan Taycan'ın tam da bu konuyu ele aldığı İki Deniz Arası adlı projesi toplam uzunluğu $60 \mathrm{~km}$ olan her biri 15 km'lik 4 etaplı bir yürüyüş rotasından oluşur. Güzergah, İstanbul'un orman ve kırsal alanlarını, su havzalarında yer alan linyit ocaklarını, yeni havalimanın1, 3. köprü yolunu, hafriyat atık alanlarını, sanayi ve toplu konut alanlarını, kentin en eski yerleşim bölgeleri Yarımburgaz Mağarası ve kent içi bostanlarını barındıran yerleri kapsar. Bir eylem olarak İki Deniz Arası, dünyayı duyumsamaya yol açan yürümenin ritmini kutsayan bir önerme ve bir davettir (Taycan 2013) (SSekil 20).

Son olarak değinilecek çalışma Burak Arıkan öncülüğünde başlatılan Mülksüzleştirme Ağları'dır. İlk versiyonu 2013 yılında yayınlanan çalışma, Graph Commons ağ alt yapısı ile desteklenen bir arayüze dayanır ve kentsel dönüşümün sermaye iktidar ilişkilerinden oluşan ağlarını görünür kılar. Gerçekleşen mega projeler veya inşaat sektöründeki ortaklıkları şirketlerin web sitesi, kamuya açık bilgi kaynakları ve çeşitli medya haberlerinden referansla kolektif bir çalışmayla veriler toplanarak haritalandırılır. Örneğin, İBB'nin paydaş1 olduğu projeler, İstanbul Havalimanı,
Yavuz Sultan Selim Köprüsü gibi projelerin iktidar sermaye ortaklığı, medya patronlarının kentsel dönüşüm enerji ve altyapı projeleri, TOKİ imtiyazından yararlanan şirketler ve projeleri gibi haritalar web sitesinde yayınlanır. Bu haritalar ile, proje sahibi şirketler ve devlet kurumları arasındaki bağlantılar ifşa edilir; sermaye örgütlenmesindeki akışkanlık, esneklik ve eğretilik nedeniyle iç içe girmiş, okunamayan ve görülemeyen ilişkileri kamuoyuna açık ve dinamik bir şekilde sunulur. Veri hegemonyasının nasıl oluştuğunu incelemek, politik bir direniş ve toplumsal mücadeleyle kesişmektedir (Yetişkin 2016). $\mathrm{Bu}$ motivasyonla ağ mecrasının yaratıcı ve eleştirel kullanma yollarını araştıran Arıkan, sadece mühendislerin ve uzmanların kullanabileceği şekilde tasarlanmış ağ haritalama ve analiz araçlarını herkesin kullanımına açmak, bu verilerini başkalarıyla paylaşıp internet üzerinden birlikte çalışmak, kişisel verilerin eleştirel ve yaratıcı kullanımı sağlamak gibi amaçlarla projesini sürdürmektedir (Şekil 21).

\section{Sonsöz}

Bugünden bakıldığında, neoliberalleşmeyle birlikte etkisini gösteren kentsel dönüşüm politikaları toplumsal eşitsizliği arttırmış, sosyal ve mekânsal ayrıştırmayı derinleştirmiştir. Kentin yaşanabilirliğini sağlayan doğal kaynaklar, su havzaları ya tahrip edilmiş ya da tümden yok edilmiştir. Kente

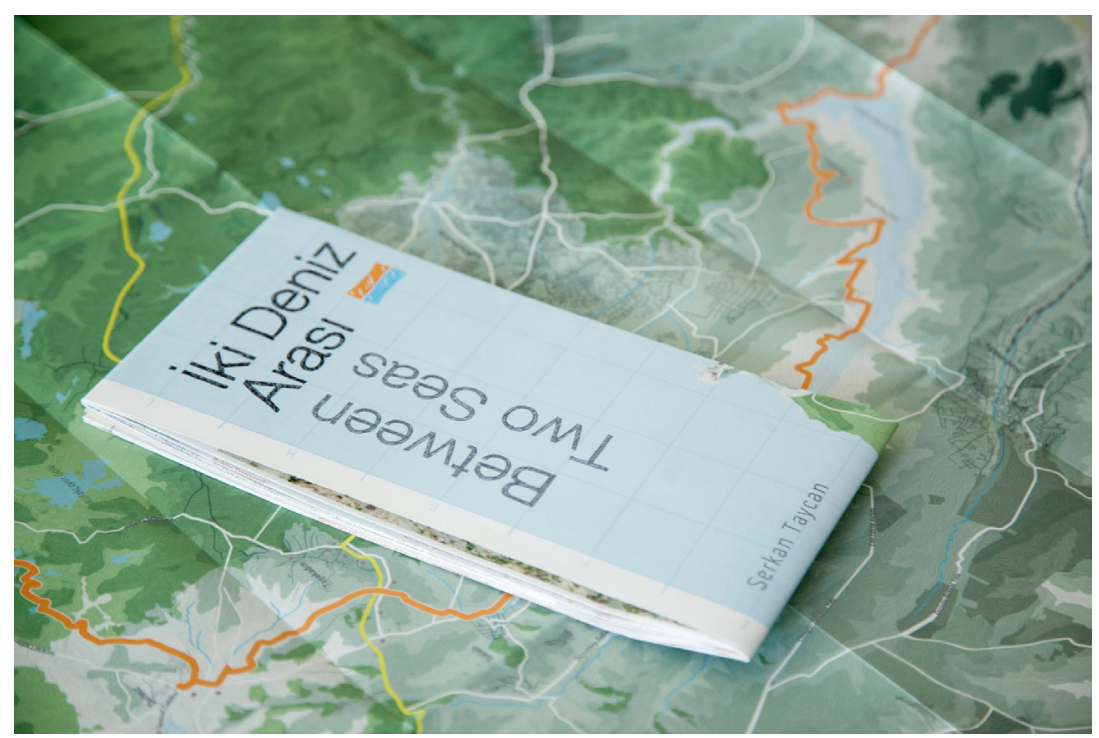




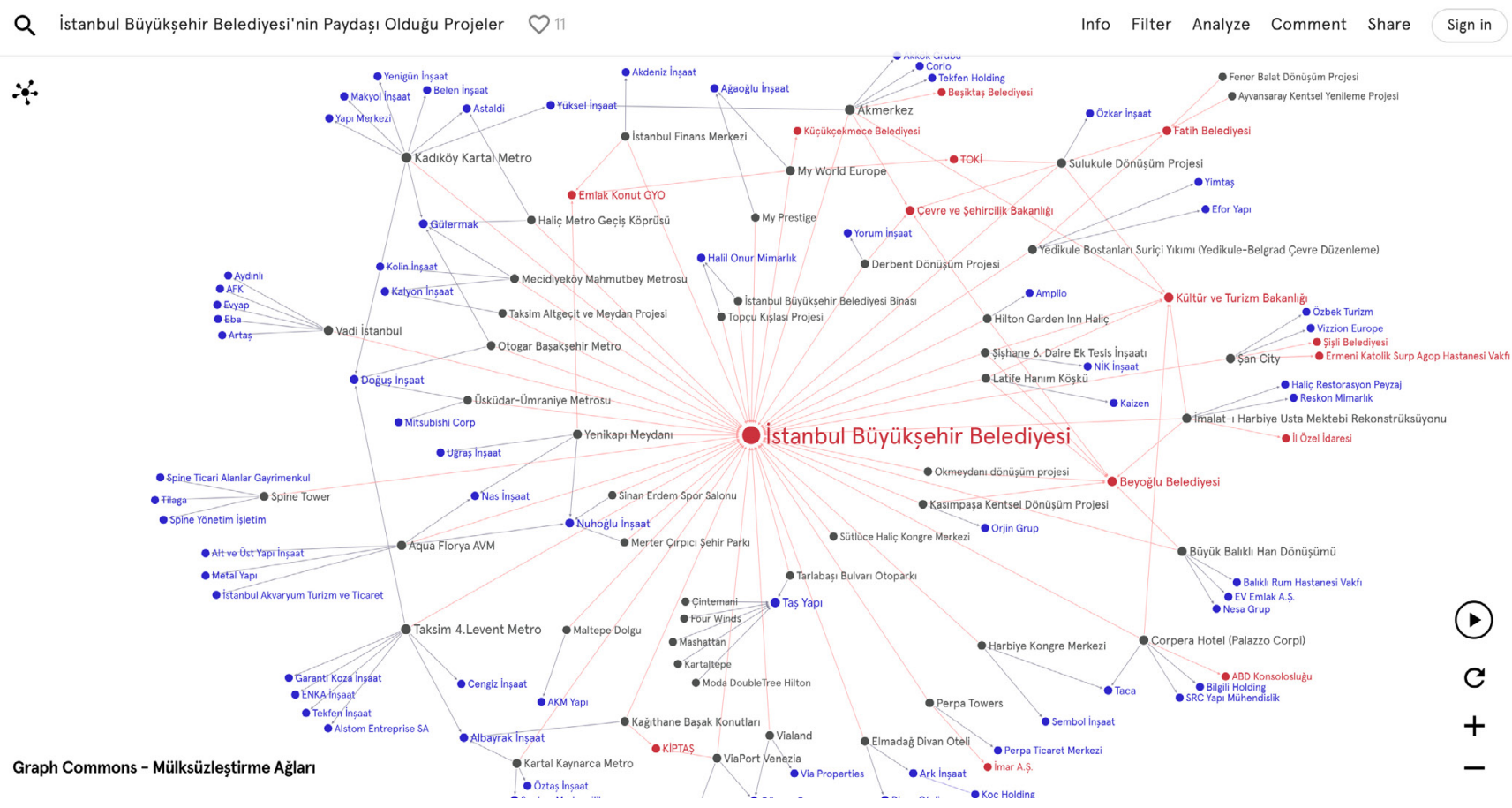

Sekil: 21

Burak Arıkan, Mülksüzleștirme Ağları, özel yazılım, 2013 - devam ediyor (Sanaţ̧ının izniyle). özgü kültürel ve tarihi eserler belli sermaye gruplarına teslim edilmiş, bu alanlarda yaşayan düşük gelirli kesimler yerinden edilme tehlikesiyle baş başa kalmıştır. Bu politikaların kaçınılmaz, ilerici, yenilikçi olma ve ekonomik canlanma iddialarının geçersizliği anlaşılmıştır (Öktem 2006). Tüketim odaklı bir kentleşme anlayışı, kenti, doğayı ve toplumu birbirine yabancılaştırmış, kültürel ilişkilenmelerini kopma boyutuna getirmiştir. Tarihten, kimlikten ve kültürel bağlardan kopuk, ortak karar alma süreçlerinden uzak, kendi ekonomik çıkarlarına hizmet eden bu mekanlar sermaye için gerekli olan kontrolü ve güvenlikli alanları oluşturmuştur.

Tüm bu süreç içerisinde kültür küreselleşmenin merkezinde yer almış, araçsallaştırılarak toplumsal gerçekliğin inşasında etkili olmaya başlamıştır. Kültürün özelleşmesi ile sermaye grupları prestijlerini arttırmış, çeşitli sponsorlukları altında gerçekleştirdikleri büyük çaplı kültür sanat etkinlikleri ile kentlerin görünürlüğü ve pazarlanmasında önemli rol oynamıştır. Özellikle 1990'lı yıllardan sonra özel sermayenin kültür ve sanat alanında hızla kurumsallaşması bu politikaların bir sonucu olarak gerçekleşmiştir. Küresel boyutta dünya piyasasına eklemlenmek, İstanbul'u en iyi şekilde pazarlamak (Keyder 1992) adına İstanbul
Bienali veya açılması için uğraşlar verilen modern müzeler kent imajı için vazgeçilmez önemdedir. Sanat ile finans piyasalarının içe içe geçtiği, emlak piyasası sanata mekân açarken, sanatın da popülerlik ve prestij sağladığı bir ilişkiden bahsedebiliriz. Günümüzde dünyada ünlü müzelerin, star mimarlara yaptırılan tasarımlarıyla, yerleştikleri bölgeyi hızla bir dönüşüme uğrattıkları bir gerçek olarak kabul edilmektedir. İstanbul'da ise rezidans, AVM ya da otel kompleksleri ile kentsel dönüşüm veya mega projelerde yer alan holdinglerin aynı zamanda büyük ölçekli sanat kurumlarını inşa ettirdiği görülmektedir. Öyle ki İstanbul belleğinin fotoğrafçısı, İstanbul belleğini imha edenler tarafindan finanse edilmektedir (Sayın, Güleryüz ve Sancaktar 2018). Bugün bu kültür-sanat kurumları, sıkı sıkıya bağlı oldukları sermaye ile ilişkileri ve şeffaf olmayan işleyişi; sivilleşme ve sosyalleşme yerine seçkinlere ve eğlenceye hitap etmeleri gibi oldukça eleştiri almaktadır (Gökçe 2017). Kurumsallaşan kültürün, gayrimenkul ve inşaat sektörüne, emlak piyasasına ve devlet yönetmeliklerine hizmet eden kentsel dönüşüm uygulamaları için araçsallaştırılarak mekânsal ayrışmanın yanı sıra müşterek tahayyülün de ayrışmasina ve toplumsal öznenin yitimine sebep 
olduğu belirtilmektedir (Tan 2013). Bu gibi çelişkilerin sanat ortamının sterilleşmesine ve de sanatın hakikatini kaybetmesine sebep olduğu düşünülebilir (Erden 2015).

Böyle bir kültürel ortamda gelişen güncel sanat ortamının en çok tartışılan konusu kendini var edebileceği mekân problemi olmuştur. Mekânsızlık karşısında kolektifler kurarak çözüm arayışı, birlikte çalışma ve ortak söz söyleme pratiklerini geliştirmiş, daha sonra bu deneyimin farklı gruplarla dayanışma kurulmasında aktarıldığını söyleyebiliriz. Sulukule örneğinde olduğu gibi, süregelen kentsel dönüşüm ve kentsel özelleştirme sürecine müdahale edebilmek için sanatsal pratiklerle kolektif bir eyleme geçmek alternatif platformlar ve karşı-kültürel mekânlar yaratmış, çeşitli eylemler ve direniş söylemleri üretilebilmiştir (Tan 2013). Bununla birlikte, Gülsuyu - Gülensu Mahallesi'nde olduğu gibi, mahalleden doğmayan bir kültür pratiğinin belgeleme, arşivleme, biriktirme araçları ile yarı özel ilişkiler ve mekânsal pratikler üzerine bir bilgi kaynağı oluşturması ve bunun nasıl kullanılacağı; mahalleye özgü paylaşımların özellikle medyadaki olumsuz imajı destekleyebileceği ve proje sponsorlarının küresel sermaye ile ilişkileri çeşitli şüphe ve eleştirinin kaynağı da olabilmiştir (Sarıyüz 2009).

Özellikle kentsel dönüsüme karșı mücadele veren mahalleler ile birlikte çalışan sanatçıların deneyimleri, Rancière'nin ifade ettiği gibi mekânın görünürlüğü ve yaşanırlığın dağılımını yeniden biçimlendirme olarak okunabilir. Nitekim, Gülsuyu - Gülensu mahalle sakini Erdoğan Yıldız, sanat ve sanatçının yaratıcılığ ile yerel bir örgütlenmenin bağının kuvvetli kurulmasının, hem mahalleli hem de sanatçı için bir özgürleşmeye yol açabileceğine işaret etmektedir. Yıldız ile birlikte çalışma yürütmüş olan Oda Projesi, kuruluşundan bu yana kendilerini iletişimi sağlayan aracılar olarak tanımlamakta ve sivilliğe vurgu yapmaktadır. Mahalle ile yürüttükleri çalıșmalar ile ortak deneyim, zaman ve mekânda hafıza kaydına dönüşmektedir ve bu kayıt tıpkı Rancière'in bahsettiği gibi olasılıklara, olası yeni kurgulara zemin hazırladığı düşünülebilir. 2000'lerden sonra hiz kazanan kent politikalarının, kentsel ve toplumsal yapıyı dönüştürdüğü gibi, güncel sanat ortamını da etkilediği ve biçimlendirdiği görülmektedir. Bu etkileşim, farklı bağlamlar kurularak çeşitli yöntemler ve pratiklerle sanatçılar tarafından ele alınmıştır. Odağını merkezden periferiye çeviren; farklı dilleri, melez kültürleri, azınlıkların ve özellikle alt kesimin problemlerini görünür kılmaya çalışan; yeni işbirlikleri icat ederek mümkünse ekonomik ve hukuki süreçleri destekleyecek projeler üreten; aynı zamanda geçmișin bilgisini bugüne aktarıp tartıșmaya açan çalışmalar olduğunu söyleyebiliriz. Bir mekânın hafızasını kaydederek geleceğe dair söylem olasılıklarını arttırmak; yeni iletișim olanaklarını kullanarak müșterek bilgi birikimini sağlamak ve bu bilgileri ortak kullanıma açmak, böylece görünmez iktidar ağlarını görünür kılmak, sorgulamak, tahakküm altına alınmış zaman ve mekânda var olan kurguları değiștirmek ve yenilerini üretmek bugün birçok sanatçının motivasyonunu oluşturmaktadır•

174 Sayı 32, Mart 2021 


\section{Kaynakça}

1. İstanbul Tasarım Bienali. (2012). 14 Mart 2020 tarihinde https://www.mimarizm.com/etkinlikler/ bulusmalar/1-istanbul-tasarim-bienali 120377 adresinden erişildi.

13B. (2013). Kavramsal Çerçeve. 14 Mart 2019 tarihinde http://13b.iksv.org/tr adresinden erișildi.

Acar, B. (2007, Mayıs). Hakan Gürsoytrak: Hafriyat'tan Evren Clkarmak. 14 Mart 2020 tarihinde http:/ www.gursoytrak.com/hakan-gursoytrak-hafriyattan-evren-cikarmak/\#more-1370 adresinden erișildi.

Adorno, T. (2008). Kültür Endüstrisi - Kültür Yönetimi. A. Artun (Ed.). (N. Ülner, M. Tüzel ve E. Gen, Cev.). İstanbul: İletișim Yayınları.

Akay, A. (2016). Çăğdaş Sanat Dinamikleri ve Sosyolojik Sanat Üzerine Başlangıç. Teorik Bakıs, , 8 , İstanbul: Minör Yayınevi, 15-20.

Artı Gerçek. (2019). Mega projelerin zararı halktan tahsil ediliyor. 14 Mart 2020 tarihinde https://amp. artigercek.com/haberler/mega-projelerin-zarari-halktan-tahsil-ediliyor adresinden erişildi.

Balaban, O. (2013). Neoliberal Yeniden Yapılanmanın Türkiye Kentleșmesine Bir Diğer Armağanı: Kentsel Dönüsümde Güncelin Gerisinde Kalmak. A. Çavdar, P. Tan (Der.). İstanbul: Müstesna Sehrin Istisna Hali içinde (ss. 51-78). İstanbul: Sel Yayıncılık.

Barker, E. (2006). Müzenin Toplumdaki Yeri: Yeni Tate Galerileri. (E. Soğancılar, Çev.). Müze ve Elesstirel Düsünce Tarih Sahneleri - Sanat Müzeleri 2 içinde (ss.149-181). A. Artun (Ed.). İstanbul: İletişim Yayınları. (Orjinal eserin yayın tarihi 1999).

Birgün Gazetesi. (2018, 3 Ekim). ‘AB ile yeni dönem' derken fon kesildi. Birgün Gazetesi. 14 Mart 2020 tarihinde https://www.birgun.net/haber-detay/ ab-ile-yeni-donem-derken-fon-kesildi-232283. html adresinden erişildi.

Block, R. (1995). 4. Uluslararası İstanbul Bienali Kataloğu. (S. Ababay, Çev.). İstanbul: İKSV.

Debord, G. (2011). Sitüasyonistler: Enternasyonel Manifesto. (U. Kılıç, Cev.). Sanat Manifestolart Avangard Sanat ve Direniş içinde (ss.320 - 323). A. Artun (Der.). İstanbul: İletişim Yayınları. (Orjinal eserin yayın tarihi 1960).

Emmelhainz, I. (2013). Sanat ve Kültürel Dönemeç: Özerk Sanatın ve Dava Sanatının Sonu mu?. (N. Örge, Cev.). Că̆das Sanat ve Kültüralizm içinde (ss. 171 - 187). A. Artun (Der.). İstanbul: İletişim Yayınlar1. (Orjinal eserin yayın tarihi 2013).

Erbaş, D. ve Leicht, B. (2008). İstanbul 7 - Şehir Hatları sergi Kataloğu. Erlangen Sanat Müzesi, 9-11.

Erdemci, F. (2014) Küratör Metni. 14 Mart 2020 tarihinde https://bienal.iksv.org/tr/bienal-arsivi/13-istanbul-bienali adresinden erişildi.

Esche, C ve Kortun, V. (2005a). 9. Uluslararası Istanbul Bienali Kataloğu. İstanbul: İKSV.

Esche, C. Kortun, V. (2005b). Genişleyen Dünyada Sanat, Kent ve Siyaset. 9. Uluslararası Istanbul Bienali'nden Metinler. İstanbul: İKSV,17-20.

Friedmann, J. ve Wolff, G. (1982). World city formation: an agenda for research and action. International Journal of Urban and Regional Research. vol.6, Issue 3 .

Gecikmez, E. (2019). Kentsel Dönüsüm ve Güncel Sanat: İstanbul'da Yaşanan Kentsel Dönüşümü Eserlerinde Konu Edinen Sanatçılar
(Yayımlanmamıs Yüksek Lisans Tezi). Yıldız Teknik Üniversitesi, İstanbul

Gökçe, H. (2017). Vasıf Kortun'dan Salt'a Eleștirel Veda: ' Kamu ve Müze Fikri Tasfiye Edildi'. SanatAtak. 14 Mart 2020 tarihinde http://www.sanatatak. com/view/vasif-kortun-kamu-muze-fikri-tasfiye-edildi adresinden erișildi.

Gürbilek, N. (2011). Vitrinde Yașamak, 1980'lerin Kültürel İklimi. İstanbul: Metis Yayınları.

Harvey, D. (2013). Asi Sehirler Sehir Hakkından Kentsel Devrime Doğru. (A. D. Temiz, Çev.). İstanbul: Metis Yayınları. (Orjinal eserin yayın tarihi 2012).

Hirsch, N ve Misselwitz, P. Kültürel Aracılar. Kültürel Aracılar 2019 - 2009. (Ö. Açıkkol, Çev.). 14 Mart 2020 tarihinde https://saltonline.org/media/ files/kulturel_aracilar_2019-2009_scrd.pdf adresinden erișildi.

İmece (Toplumun Şehircilik Hareketi). (2013). 13 Istanbul Bienali: Buyrun Simyaya. e-skop. 14 Mart 2020 tarihinde http://www.e-skop.com/ skopbulten/13-istanbul-bienali-buyrun-simyaya/1361\# ednref3 adresinden erișildi.

İstanbul 2010 Avrupa Kültür Başkenti 2010 Programı, (2010)

Kahraman, T. (2013). Kent hukukunun yeni yüzü: Düzenleyici devletten seçkinleştirici devlete. A. Cavdar, P. Tan (Der). Istanbul: Müstesna Sehrin Ístisna Hali içinde (ss. 17 - 47). İstanbul: Sel Yayıncilık.

Kamhi, R. (2013). Değişen Kent Ortamında Hafıza Mekan ve Sanat Yapıtı Iliskisi. (Yayımlanmamıs yüksek lisans tezi). Y1ldız Teknik Üniversitesi, İstanbul.

Kamusal Sanat Laboratuvar1. (2011). Ísimsiz Mektup (Bienal). 14 Mart 2020 tarihinde http://kamusalsanatlaboratuvari.blogspot.com/p/isimsiz-mektup-bienal.html adresinden erișildi.

Keyder, Ç. (1992). İstanbul'u Nasıl Satmall. İstanbul Dergisi, 3, 81-86.

Kosova, E. (2015). Bitimsiz Kavisler: Türkiye'de Siyasal Dinamiklerin Sanat Alanına Yansımaları. 77/13 Türkiye'de Direnișin Sanatı içinde (ss.135 -143). Berlin: nGbK

Kreft, L. (2014). Sanat ve Siyaset: Sanatın Siyaseti ve Siyasetin Sanat1. (E. Gen, Cev.). Sanat/Siyaset Kültür Çă̆ında Sanat ve Kültürel Politika içinde (ss. 9 - 48). A. Artun (Ed.). İstanbul: İletişim Yayınlar1.

Kuryel, A ve Firat, B.Ö. (2015). Sunuş. Küresel Ayaklanmalar Çăglnda Direnis ve Estetik. Kuryel, A. Fırat ve B.Ö. (Der.). İstanbul: İletişim Yayınlar1.

Logie, S. ve Morvan, Y. (2017). İstanbul 2023. İstanbul: İletişim Yayınları.

Madra, B. (2003). Iki Yılda Bir Sanat, Bienal Yazıları 19872003. İstanbul: Norgunk Yayınları.

Marcuse, H. (1991). Karşı Devrim ve Başkaldırı. İstanbul: Ara Yayıncılık. (Orjinal eserin yayın tarihi 1972).

Mc Donough, T. (2004). Taskın Paris: Paranoyak Eleştirel Bir Eylem Olarak Haritaya Dökme. (B. Ergener, Çev.). art - ist güncel sanat dergisi, 1. İstanbul, $148-169$.

Mülksüzleștirme Ağları. 14 Mart 2020 tarihinde http:// mulksuzlestirme.org/ adresinden erişildi.

Öktem, B. (2006). Neoliberal Küreselleșmenin Kentlerde İnşası: AKP'nin Küresel Kent Söylemi ve İstanbul'un Kentsel Dönüșüm Projeleri. 
Planlama Dergisi, 36, Ankara: TMMOB Şehir Planciları Odas1, 53-63.

Rancière, J. (2007). Siyasi Özne Olarak Sanatçılar ve Kültür Üreticileri: Neo-Liberal Küreselleșme Döneminde Muhaliflik, Müdahale, Katılımcılık, Özgürleşme. Olasılıklar, Duruşlar, Müzakere, Güncel Sanatta Kamusal Alan Tartışmaları içinde (ss. 129-132). P. Tan, S. Boynik (Der.). İstanbul: İstanbul Bilgi Üniversitesi Yayınları.

Sarıyüz, E. (2009). Başka Mekanlarda Kurumsal Kültür Pratikleri. Kültürel Aracılar 2019 - 2009. 14 Mart 2020 tarihinde https://saltonline.org/media/ files/kulturel aracilar_2019-2009 scrd.pdf adresinden erişildi.

Sassen, S. (1991). The Global City: New York, London, Tokyo. New Jersey: Princeton University Press.

Sayın, Z., Güleryüz, B. ve Sancaktar, S. (2018). Tarihi Taşımak ya da Düşürmek: Ara Güler. 14 Mart 2020 tarihinde http://www.e-skop.com/skopbulten/tarihi-tasimak-ya-da-dusurmek-ara-guler/3894 adresinden erişildi.

Smith, N. (2002). New Globalism, New Urbanism: Gentrification as Global Urban Strategy. Antipode, 34, 427 - 449.

Stallabrass, J. (2009). Sanat A.Ş, Çă̆daş Sanat ve Bienaller. (E. Soğancılar, Çev.). İstanbul: İletişim Yayınları. (Orjinal eserin yayın tarihi 2004).

Steyerl, H. (2013). Sanatın Politikası: Çağdaș Sanat ve Post-Demokrasiye Geçiş. (Z. Baransel, Çev.). Çağdaş Sanat Nedir? Modernlik Sonrasında Sanat içinde (ss. 83 -93). A. Artun, N. Örge (Ed.). İstanbul: İletişim Yayınları. (Orjinal eserin yayın tarihi 2012).

Sulukule Günlüğü. 14 Mart 2020 tarihinde http://sulukulegunlugu.blogspot.com/adresinden erişildi.

Sen, B. (2005). Soylulaştırma: Kentsel Mekanda Yeni Bir Ayrışma Biçimi. H. Kurtuluş (Haz.) İstanbul'da Kentsel Ayrışma içinde (ss.127 - 159). Ankara: Bağlam Yayıncılık.

Tan, P. (2013). Yerellik, direniş ve mekansal hakkaniyet: Felaketin yanından koşmak. İstanbul: Müstesna Şehrin Ístisna Hali içinde (ss. 179 - 190). A. Çavdar, P. Tan (Der). İstanbul: Sel Yayıncılık.

Taptık, A. (2016). Osmanbey'e Bakmak. 14 Mart 2020 tarihinde http://www.alitaptik.com/index.php?/ works/osmanbey/ adresinden erişildi.

Taycan, S. (2013). İki deniz arası. Harita. İstanbul: Mas Matbaa.

Türkün, A. (2014). Kentsel Ayrıșmanın Son Așaması Olarak Kentsel Dönüşüm. Mülk, Mahal, İnsan, Ístanbul'da Kentsel Dönüşüm içinde (ss. 3 15). A. Türkün (Der). İstanbul: İstanbul Bilgi Üniversitesi Yayınları.

Uşaklıgil, E. (2014). Bir Şehri Yok Etmek, İstanbul'da Kazanmak Ya Da Kaybetmek. İstanbul: Can Sanat Yayınları

Wu, C. (2005). Kültürün Özelleştirilmesi. (E. Soğancılar, Çev.). İstanbul: İletişim Yayınları. (Orjinal eserin yayın tarihi 2002).

Yardımcı, S. (2005). Kentsel Değişim ve Festivalizm: Küreselleșen İstanbul'da Bienal. İstanbul: İletişim Yayınları.

Yetişkin, E. (2016). Sanat-Hafıza Kürasyonu: Sömürünün Güncel B(ağ)ları, Veri Hegemonyası, Yeni Maduniyet. Teorik Bakış, 8, 154-155.

Y1ldız, E. (2011). Kültürel Aracılar ve Olası Etkileri Üzerine. Red Thread, 1-3, İstanbul, 42 - 47.

Y1lmaztürk, C. S. (2018). Bir Kentin Y1kımı ya da Y1kılan
Kente Ağıt: Tarlabaşı Tarlabaşı. Tarlabaşı Bir Kent Mücadelesi içinde (ss. 93 - 111). İstanbul TMMOB Mimarlar Odası İstanbul Büyükkent Şubesi.

Zeytinoğlu, E. (2004). 'Yer'in Altını Üstünü Getirmek: Hafriyat. Hafriyat Yalan Dünya. Münih. 